BEFORE THE FALL: WERE EAST ASIAN CURRENCIES OVERVALUED?

\author{
Menzie D. Chinn
}

Working Paper 6491 
NBER WORKING PAPER SERIES

\section{BEFORE THE FALL: WERE EAST ASIAN CURRENCIES OVERVALUED?}

Menzie D. Chinn

Working Paper 6491

http://www.nber.org/papers/w6491

\section{NATIONAL BUREAU OF ECONOMIC RESEARCH 1050 Massachusetts Avenue Cambridge, MA 02138 April 1998}

I thank, without implicating, Yin-Wong Cheung, Hamid Faruqee, Ilan Goldfajn, Steve Radelet and seminar participants at the International Monetary Fund Research Department for useful comments, and the Federal Reserve Bank of San Francisco's Center for Pacific Basin Monetary and Economic Studies and the Hong Kong Census and Statistics Department for providing data. Financial support of faculty research funds of the University of California is gratefully acknowledged. Any opinions expressed are those of the author and not those of the National Bureau of Economic Research.

(C) 1998 by Menzie D. Chinn. All rights reserved. Short sections of text, not to exceed two paragraphs, may be quoted without explicit permission provided that full credit, including (C notice, is given to the source. 
Before the Fall: Were East Asian Currencies Overvalued?

Menzie D. Chinn

NBER Working Paper No. 6491

April 1998

JEL Nos. F31, F41, F47

\begin{abstract}
$\underline{\text { ABSTRACT }}$
I implement two major approaches to identifying the equilibrium exchange rate. First, the concept of purchasing power parity is tested and used to define the equilibrium real exchange rate for the Indonesian rupiah, Korean won, Malaysian ringgit, Philippine peso, Singapore dollar, Taiwanese dollar and the Thai baht. The calculated PPP rates are then used to evaluate whether these seven East Asian currencies were overvalued. The purchasing power parity calculations are performed on broad price indices, price indices of tradable goods, and price indices of export goods using the Johansen and Horvath-Watson cointegration test procedures. As of May 1997, the baht, ringgit and peso were overvalued according to this criterion. While the overvaluations are not large, they do appear to be persistent. Robustness checks for sensitivity to deflator, sample period, and numeraire currency are undertaken. Second, I calculate the implied equilibrium rates from a monetary model augmented by a proxy variable for productivity trends. The monetary models imply less substantial deviations from equilibrium. Furthermore, the results do not closely correspond to those obtained from the PPP calculations. Interestingly, both methods indicate that the Korean won was undervalued even before its recent discrete drop in value.
\end{abstract}

\author{
Menzie D. Chinn \\ Department of Economics \\ Social Sciences I \\ University of California \\ Santa Cruz, CA 95064 \\ and NBER \\ chinn@cats.ucsc.edu
}




\section{INTRODUCTION}

In the wake of the East Asian currency crises of 1997, the central question is what caused the precipitous declines in exchange rates. Since all the regional currencies, save Hong Kong's, lost value, the natural supposition is that these currencies -- the Thai baht, Indonesian rupiah and Malaysian ringgit most prominently -- were overvalued on the eve of the crisis (see Figure 1). In fact, however, currencies not previously thought to be overvalued such as the Korean won, Singapore dollar and Taiwanese dollar, also depreciated (see Figure 2) suggesting that the characterization of overvaluation is often applied tautologically.

In this paper, I attempt to take the issue of "overvaluation" seriously from an econometric standpoint. The lack of an operational definition of overvaluation is troubling because a number of authors, perhaps most notably Dornbusch, Goldfajn and Valdes (1995), have argued that overvaluation according to some price measure is the key determinant of a

subsequent currency crash. On the opposite end of the spectrum, Dooley (1997) has forwarded the proposition that the moral hazard introduced by implicitly insured banks and the government's guarantee of conversion at a fixed exchange rate provides the channel for a currency crisis. In between there is a whole spectrum of views that ascribe causality to a combination of these factors.

In order to investigate whether the East Asian currencies were overvalued, one needs to select a plausible and operationally useful definition of overvaluation. There are at least three broad definitions in use (see Milesi-Ferretti and Razin, 1996, and Williamson, 1994):

1. Price based criteria, such as purchasing power parity and its variants.

2. Model based criteria, based on a formal model of nominal exchange rates. 
3. Solvency and sustainability based criteria, which make reference to trends in the current account and the external debt to GDP ratio.

It turns out that the relevance of each criterion is inversely related to the difficulty of implementing it. Price based criteria are relatively easy to implement, but do not address the economically interesting question of whether a particular exchange rate is at an "optimal level", besides that defined by a no-arbitrage condition. On the other hand, the sustainability measures can make reference to an optimal level, but are very difficult to calculate as they require a fully-fleshed out macroeconomic model (e.g. see Bayoumi et al. (1994) and Driver and Wren-Lewis (1996)). Moreover, in order to make a statement about optimality, they need to take a stand on representative agent behavior. Consequently, in this paper I set out to meet the more modest goals of implementing the first two criteria.

The paper proceeds in the following manner. In section 2 , the price based measures are described, the tests for purchasing power parity undertaken, and the calculations of equilibrium rates reported. In section 3, a monetary model of nominal exchange rates, augmented by a relative price variable that proxies for productivity differentials, is estimated, and then used to calculate the equilibrium exchange rates. Section 4 concludes.

To anticipate the results, I find that there is evidence that real exchange rates defined using producer price indices are mean reverting over the $1975-96$ period. According to this measure of equilibrium, the Malaysian ringgit, Thai baht and Philippine peso were overvalued on the eve of the 1997 crisis. Surprisingly, the Indonesian rupiah does not show up as overvalued unless the reference period is restricted to the $1986-96$ period. I also obtain evidence of cointegrating relationships between exchange rates, monetary fundamentals, and 
the relative price of tradables and nontradables for these East Asian currencies. However, the implied dis-equilibria are not consonant with those obtained using the price-based measures. Rather, they indicate rough equilibrium at the end of the first quarter of 1997, with the exception of a substantial overvaluation for the Singapore dollar, and an undervaluation of the Philippine peso.

\section{PRICE BASED MEASURES OF EQUILIBRIUM REAL EXCHANGE}

\section{RATES}

\subsection{Theoretical Background to Purchasing Power Parity}

The equilibrium exchange rate is often associated with an international version of the Law of One Price (LOP): abstracting from transport costs, identical goods in different countries have the same price, when expressed in common currency terms

$$
s_{t}+p_{t}^{i *}=p_{i}^{i}
$$

where $s_{t}$ is the exchange rate in US\$/local currency unit (¥/local currency unit), $p_{t}^{i}$ is the price of a US (Japanese) widget, and $p^{i *}$, is the price of a local widget in foreign currency units. An arbitrage argument is usually offered to explain why this condition should hold.

At this juncture, data limitations intrude. Typically, one does not have prices for identical goods; rather one observes price indices, $p$, for bundles of goods. These indices do not usually ascribe the same weights to each good, nor are the quality attributes of these goods the same, so that direct testing of LOP is not possible. What one can test is how well purchasing power parity (PPP) holds up to a constant $\kappa$ which depends upon the base year of 
the price indices,

$$
\begin{gathered}
s_{t}+p_{t}^{*}=p_{t}+\kappa \\
\Rightarrow \quad q_{t} \equiv s_{t}-p_{t}+p_{t}^{*}-\kappa
\end{gathered}
$$

where $q$ is the real exchange rate.

The consensus in the profession is that PPP clearly does not hold continuously, and perhaps does not hold even over long periods, when one interprets the price index as one pertaining to a broad set of goods and services (see Breuer, 1994; Froot and Rogoff, 1995). ${ }^{1}$ Since some of the items in a typical consumption or production bundle are not tradable and subject to international price pressures from international trade, this result is not completely unexpected. On the other hand, since consumer bundles might be more similar across countries than producer or wholesale bundles, consumer price indices (CPIs) may provide a more consistent measure of price levels and thus of real exchange rates. ${ }^{2}$

I am agnostic on the issue, so I also consider a measure using as a proxy the wholesale or producer price index (WPI or PPI), which covers goods considered to be highly tradable. ${ }^{3}$ Finally, if the countries of interest are primarily exporting to third country markets, then the export price index may in principle be the more appropriate deflator. In practice, export unit value indices are notoriously subject to measurement error; moreover, the composition of the bundles of exports are likely to vary even more widely across countries

${ }^{1}$ For a contrasting view, see the recent panel work by Frankel and Rose (1996), MacDonald (1996), Oh (1996) and Wu (1996).

${ }^{2} \mathrm{I}$ thank Wing Woo for pointing this possibility out to me.

${ }^{3}$ See Engel (1995) for a contrasting view of the behavior of "tradables" prices. 
than the corresponding PPI or CPI bundles.

It is useful to explicitly define my usage of the term PPP. I consider PPP as a concept applicable to price indices, whereas other researchers consider tests applied to narrow price indices a test for the law of one price. I do not take a stand on which term is better; merely that some form of price equalization constitutes a definition of equilibrium.

\subsection{Methodology}

The standard approach to testing for an equilibrium real exchange rate based on prices is to implement a unit root test, such as the following Augmented Dickey-Fuller (ADF) regression,

$$
\Delta q_{t}=\gamma_{0}+\Gamma q_{t-1}+\sum_{i=1}^{k} \gamma_{i} \Delta q_{t-i}+\epsilon_{z}
$$

which yields an estimate of the rate of reversion toward PPP of $\Gamma<0$. As is well known, such tests possess low power against local alternatives. Hence previous attempts to find mean reversion in the post-Bretton Woods period, using univariate techniques, have usually failed. ${ }^{4}$

The low power of such unit root tests may be due to the imposition of inappropriate common factor restrictions implicit in the ADF specification (Kremers, Ericsson and Dolado, 1992). In estimating an ADF on the real exchange rate, one forces the short run dynamics for the exchange rate and both price levels to be the same. In principle, there is no reason to believe that this condition should hold. A more general specification implied by cointegration is:

\footnotetext{
${ }^{4}$ For an exception see Cheung and Lai, 1996.
} 


$$
\begin{aligned}
& \Delta s_{t}=\gamma_{10}+\Phi_{1}\left[\beta_{1} s_{t-1}+\beta_{2} p_{t-1}+\beta_{3} p_{t-1}^{*}\right]+\sum_{i=1}^{k} \gamma_{1 i} \Delta s_{t-i}+\sum_{i=1}^{k} \zeta_{1 i} \Delta p_{t-i}+\sum_{1=i}^{k} v_{1 i} \Delta p_{t-i}^{*}+\epsilon_{1 t} \\
& \Delta p_{t}=\gamma_{20}+\Phi_{2}\left[\beta_{1} s_{t-1}+\beta_{2} p_{t-1}+\beta_{3} p_{t-1}^{*}\right]+\sum_{i=1}^{k} \gamma_{2 i} \Delta s_{t-i}+\sum_{i=1}^{k} \zeta_{2 i} \Delta p_{t-i}+\sum_{\substack{1=i \\
k}}^{k} v_{2 i} \Delta p_{t-i}^{*}+\epsilon_{2 t} \\
& \Delta p_{t}^{*}=\gamma_{30}+\Phi_{3}\left[\beta_{1} s_{t-1}+\beta_{2} p_{t-1}+\beta_{3} p_{t-1}^{*}\right]+\sum_{i=1}^{k} \gamma_{3 i} \Delta s_{t-i}+\sum_{i=1}^{k} \zeta_{3 i} \Delta p_{t-i}+\sum_{1=i}^{k} v_{3 i} \Delta p_{t-i}^{*}+\epsilon_{3 t}
\end{aligned}
$$

Johansen (1988) and Johansen and Juselius (1990) describe the maximum likelihood method of estimating this vector error correction model (VECM) and for testing cointegration. A likelihood ratio test can be applied to the restriction that $\left(\beta_{1} \beta_{2} \beta_{3}\right)$ takes on the value $(1-1$ 1). Cheung and Lai (1993b) are among the first to apply this approach; they find evidence for cointegration, but reject the unitary coefficient restriction implied by strict PPP.

Since one has prior information on the form of the cointegrating vector, a more powerful test of the null of no cointegration against the alternative of cointegration with a prespecified cointegrating vector can be applied. Horvath and Watson (1995) tabulate the critical values for a Wald test on the $\Phi$ coefficients equaling zero. Rejection of this null hypothesis implies cointegration because the variables, either singly or jointly, revert back to the conditional mean defined by the cointegrating vector. Edison, Gagnon and Melick (1997) apply this test to the post-Bretton Woods data for the G-7 and find mixed evidence for PPP.

\subsection{Data}

The countries of interest are Hong Kong-PRC, Indonesia, Korea, Malaysia, the Philippines, Singapore, Taiwan, and Thailand. I generate a number of bilateral real exchange rates against the US dollar and the Japanese yen. Most series are from the November 1997 IMF Intemational Financial Statistics CD-ROM, and span the 1970.01-1997.09 period. The 
Taiwanese data are from Bank of China, Financial Statistics, various issues, as recorded in Federal Reserve Bank of San Francisco electronic database. The exchange rates are end-ofmonth data, expressed in US\$/local currency unit [inverse of IFS line ae]. Exchange rates against the yen are calculated by dividing by the US\$\% rate.

For the broad based deflator, I use the CPI [IFS line 64]. For the "tradable" price based deflator, I use the PPI or WPI data reported in IFS line 63. The Indonesian PPI data exclude petroleum products [IFS line 63a], while the Hong Kong PPI data are quarterly, from the Hong Kong Department of Census and Statistics. The export price data is the export unit value index [IFS line 74].

In principle, one might like to use a trade weighted measures of the real exchange rate. The problem that one encounters is that the pattern of trade flows change substantially over the sample period and hence so too do the appropriate trade-weights. Nonetheless, I also examine the trade-weighted PPI deflated real exchange rates reported by Morgan-Guaranty. ${ }^{5}$ The bilateral (against US dollar and yen) PPI-deflated exchange rates (re-scaled to have a base of zero (in log terms) in 1990) are presented in Figures 3-10 for the East Asian currencies examined.

The time series patterns of the multilateral exchange rates do not differ greatly between those of the two bilateral exchange rates, except in a couple instances, most

5 These are the"broad" effective exchange rate indices, based on 1990 trade weights for the 1987-97 period. Prior to that, the 1980 trade weights are used. See World Financial Markets (1993). Note that the HK series is calculated using a Hong Kong retail price series, rather than a PPI. The nontradable component of retails sales may explain the rapid post-1990 appreciation of the Hong Kong dollar against the US dollar. 
prominently the Taiwanese dollar. ${ }^{6}$ It turns out that the results using only the bilateral exchange rates will in general be sufficient to make inferences regarding stationarity of the real exchange rate. This outcome makes sense as the US and Japan accounted for a large portion of these countries' imports and exports in 1996 (see Appendix 1).

Table 1 presents some summary statistics on stochastic trends in the various real exchange rate measures estimated from the regression

$$
\Delta q_{t}=\delta+u_{t}
$$

There is no obvious difference in the drift estimates for the bilateral CPI-deflated dollar and yen series. The drift term estimates range from a depreciation of $0.0047 / \mathrm{mo}$. ( $5.6 \%$ per year) of the Indonesian rupiah against the dollar, to an appreciation of $0.0009 / \mathrm{mo}$. (1.1\% per year) of the New Taiwan dollar against the US dollar. The Hong Kong dollar drift estimates are not strictly comparable with the other estimates because the bilateral CPI series only begins in 1990. However the rate of appreciation over this period is remarkable -- $5.3 \%$ per year.

In contrast, the drift term for the PPI adjusted exchange rates are typically smaller (in absolute value) than their CPI-deflated counterparts. Furthermore, none of the drift estimates are statistically significant. These two results suggest that PPI's are a better measure of tradables prices than CPI's.

Interestingly, the real exchange rates defined using export price indices exhibit substantial drift terms. For the most part, the real exchange rates are depreciating against the

${ }^{6}$ Note that while there are large divergences in the early period, the analysis will be conducted on the floating rate period data, starting from 1975. Hence, the large divergences evident in the early 1970s do not influence the subsequent econometric analysis. 
dollar and yen. The only exception is the Singapore dollar. The presence of substantial, but imprecisely estimated, drift terms suggests that such price indices are subject to greater measurement error. In particular, the export bundles of these NICs have probably changed substantially over time, introducing drift in the price indices ${ }^{7}$ (the Japanese yen is an exception; it is likely that the composition of the Japanese export bundle has changed less drastically over the sample period). Given the results reported above, the subsequent analysis will focus on the PPI deflated real exchange rates.

\subsection{Empinical Results}

\subsubsection{Unit Root and Johansen Test Results}

The ADF test was applied to all the real exchange rate series over the 1975-1996 period. By omitting the post-crisis observations, I bias the tests against finding mean reversion. Only about four cases appeared to be stationary, a proportion about consistent with what would be expected to occur by chance.

The results of applying the Johansen procedure are reported in Table 2. Panel 2.1 presents the CPI results. The Japanese yen results are included for purposes of comparison. Excepting Indonesia, there is evidence of cointegration, even using the finite sample critical values (Cheung and Lai, 1993a). However, there are quite a few perversely signed and statistically significant coefficients. For instance according to the Johansen estimates, for each $1 \%$ rise in the Hong Kong CPI, the Hong Kong dollar appreciates by $0.14 \%$; a $1 \%$ rise in the US CPI depreciates the Hong Kong dollar against the US dollar.

${ }^{7}$ Ito, Isard and Symansky (1996) argue that machine exports have increased substantially for these East Asian countries, thus contributing to real exchange rate appreciation as measured using standard deflators which include nontradables. 
Skipping to the export price deflated exchange rate results in panel 2.3 , one finds that the US export price index either enters in with incorrect sign, or correct sign and significant difference from the anticipated unitary coefficient (excepting the Philippine peso).

On the other hand, the PPI based results in panel 2.2 indicate some support for the PPP hypothesis in two cases: the Korean won and the Singapore dollar. While the Philippine peso and the Taiwan dollar also fit into the model qualitatively, the null hypothesis of unitary coefficients on the US PPI is rejected.

\subsubsection{Horvath-Watson Results}

Table 3 reports the results of applying the Horvath Watson procedure. In all instances the Wald test statistic resoundingly rejects the no-cointegration null hypothesis. However, in the CPI cases, the half-life of a deviation is typically very long, sometimes implausibly so. Similar results are obtained for the export price deflated rates.

For the PPI deflated rates, the implied half life ranges from 2 to 8.2 years (or 1.7 to 4 years using only the individually significant reversion coefficients). Only in the case of the Philippine peso and the Thai baht does there appear to be no reversion.

Table 4 reports the Horvath-Watson procedure results for PPI-deflated exchange rates expressed against the yen. Once again, the data reject the no cointegration null. However, the reversion rate is more rapid in three cases -- the Malaysian ringgit, Philippine peso and Thai baht. On the other hand, the won/yen rate does not mean-revert, which is surprising given the apparently close link between the Korean and Japanese economies.

These overall positive results contrast with those in reported in previous studies of East Asian currencies. Bahmani-Oskooee (1993) fails to find cointegration in any case but the 
Philippine CPI-deflated trade-weighted real exchange rate. His point estimate of $\beta$ in the Engle-Granger regression

$$
p_{t}=\beta_{0}+\beta\left(s_{t}+p_{t}^{*}\right)+u_{t}
$$

is 0.86 , but it is not clear whether this estimate is statistically different from unity. Tang and Butiong (1994) also use bilateral exchange rates. Out of the six PPI deflated rates they test, cointegration is found only in the case of the Philippine peso (with a point estimate on $\beta$ of $0.90)$.

Phylaktis and Kassimatis (1994) obtain more positive results; they find mean stationarity in real PPI deflated exchange rates of the Korean won, Malaysian ringgit and Philippine peso over the $1974-87$ period. Therefore, the results reported above are much more favorable to the PPP hypothesis than those obtained in previous studies of the East Asian currencies.

\subsection{Estimated Equilibrium Rates}

Based on the Horvath-Watson test results, mean stationarity of the real rate against the US dollar (and not merely a cointegrating relationship between the nominal exchange rate and price levels) is found in all cases, save the Philippine peso and Thai baht. However, since these rates expressed against the yen are found to be stationary, and the yen is found to be stationary against the dollar, then effectively all the exchange rates are stationary against the dollar.

The real exchange rates are centered using a regression of the real rate on a constant over the 1975-96 period. Note that in omitting the post-crisis observations, I bias the 
procedure against detecting an overvaluation. In some previous studies, the predicted real rate has been allowed to move with a linear deterministic trend (e.g., one of the detrended series considered in Goldfajn and Valdes, 1996). The argument in favor of using a CPI measure relies on the belief that the price of tradables may be tied to that of nontradables in the short run, so that CPI deviations from trend may constitute a better measure of disequlibrium. Without judgement, I compare my results against such an alternative measure. Hence, I calculate an alternative estimate of the equilibrium rate which allows for a trend in the CPIdeflated exchange rate,

$$
q_{t}^{C P I}=\mu_{0}+\mu_{1} \tau+v_{t}
$$

where $\tau$ is a time trend.

The implied over- and undervaluations derived from the PPI-measures are broadly consistent with historical accounts. For instance, this measure implies that the Singapore dollar was overvalued in 1979-82 period, while Moreno (1988: 192) asserts that Singapore's industry lost competitiveness during this period. By contrast, Hong Kong did not experience a substantial deterioration in competitiveness during this period, a view confirmed by the Hong Kong export-price deflated measure. Perhaps the strongest confirmation of this approach's utility comes from the won overvaluation indicated at the end of the 1970's, an overvaluation that coincides with the extreme deterioration in the Korean external accounts.

The equilibrium rates and actual levels from 1990 onward are plotted in Figures 11-18. The over- and undervaluation calculations for 1997.05 and the two year period preceding that are presented in Table 5. The results indicate a May 1997 overvaluation of the Malaysian 
ringgit (8\%), Philippine peso (19\%) and Thai baht $(7 \%)$. By way of comparison, the CPI $\mathrm{w} /$ trend measures imply larger overvaluations of $17 \%, 24 \%$ and $13 \%$, respectively. Moreover, this latter calculation implies that the Indonesian rupiah was also overvalued by $30 \%$ (as opposed to the $5 \%$ undervaluation I obtain using PPIs). While it may be tempting to point to these results as support for the high overvaluation view, it is not clear that such conclusions are warranted exactly because the econometric evidence does not suggest trend stationarity of the CPI-deflated real exchange rate.

Inspecting the deviations over the two years preceding the crisis does not change the overall pattern of results very much. Two anomalous implications of the CPI-based measures are that the Singapore dollar is substantially overvalued (13\%), while the Japanese yen is undervalued $(16 \%)$ over this period.

\subsection{Robustness Checks}

Given our uncertainty regarding all types of PPP calculations, it makes sense to undertake some robustness checks against the use of different sample periods and of alternative currencies (these detailed results are reported in Chinn (1998)). First, I recalculated the equilibrium values, using the 1986.01-1996.12 period instead of the 1975.011996.12. If the real exchange rate series were truly mean stationary, changing the sample period should not matter very much, and in fact, the estimates do not change significantly, with the exception of the Indonesian rupiah. In this case, the rupiah is estimated to be about $9 \%$ overvalued as of 1997.05 , as well as for the two year period preceding that.

I also estimated the deviations for the yen rates. These PPI-based results are at some variance with the previous results. They indicate that as of May 1997, all the East Asian 
currencies were undervalued except the Malaysian ringgit and Philippine peso. On the other hand, the CPI-based estimates yield very high overvaluations -- as high as $29 \%$ for the Thai baht and $46 \%$ for the Indonesian rupiah!

Calculations based on the Morgan Guaranty PPI-deflated series suggest that only the Philippine peso and the Singapore dollar were overvalued. (The Hong Kong dollar is also overvalued, but this series is based on a retail price index for Hong Kong, which arguably includes a sizable nontradable component.)

Why do these calculations for the (PPI-deflated) yen and the trade-weighted rates yield such counter-intuitive results? For the yen rates, it may be relevant that, with the exception of Indonesia, ${ }^{8}$ the US accounted for a larger share of these countries' exports than did Japan. If the sensitivity of trade flows is on the export side, then one might place greater importance on the US dollar based calculations of overvaluation. To the extent that the US constitutes the single largest export market for most of these countries (see Appendix Table 1), then the trade-weighted indices suffer from a similar deficiency.

Perhaps a more important reason for the failure to find overvaluation is that the calculations always consider comparisons of relative prices between the local country and the US (or Japan). Perhaps the relevant comparison is between two currencies of countries exporting to a third market, like the US or Japan. While the Morgan Guaranty series real exchange rate series are supposed to account for effects of competition in third-countries,

${ }^{8}$ The fact that Indonesia devotes a larger share of its exports to Japan is attributable to Japan's dependence of imported oil.

${ }^{9}$ It is not made clear in the supporting documentation how these third-country effects are taken into account statistically. 
their calculations omit the effects of China. This deficiency may account for the failure to identify significant overvaluation in the East Asian currencies, since the Chinese Renminbi depreciates substantially in the wake of the exchange rate unification implemented in 1994 . The deterioration of relative competitiveness (to China) of the Thai baht, Indonesian rupiah and Malaysian rupiah is illustrated in Figure 19. As is readily apparent, the Renminbi drops in value relative to the other Southeast Asian currencies; to the extent that the Chinese real exchange rate series is deflated by the $\mathrm{CPI}^{10}$ (no PPI being available) the improvement in Chinese competitiveness vis-à-vis the other Southeast Asian competitors is understated in this figure.

Huh and Kasa (1997) argue, based on a game-theoretic model drawing on the Rotemberg and Saloner (1986) explanation of price wars, that China's role is central to explaining the development of the East Asian currency crisis. ${ }^{11}$ Proper accounting for the Chinese effect is reserved for future research.

\section{A MODEL-BASED MEASURE OF OVERVALUATION}

\subsection{The Monetary Model of Nominal Exchange Rates ${ }^{12}$}

The asset-based approach to monetary models of the exchange rate relies upon a money demand equation of the form:

${ }^{10}$ The Chinese CPI is estimated. See the Data Appendix.

11 The effective depreciation of the Renminbi has been disputed by Liu et al. (1998). They note that as much as $80 \%$ of external transactions in 1993 were already taking place at the swap, rather than official, exchange rate. Using this information to calculate the effective rate in 1994 implies that from that point to 1996 , the Renminbi had appreciated $28 \%$ in log terms (Table 2)

${ }^{12}$ This portion of the paper is drawn from Chinn (1997a). 


$$
m_{t}^{d}-p_{t}=\phi y_{z}-\lambda i_{t}
$$

where $m_{t}$ is the $(\log )$ nominal money stock, $p_{t}$ is the $(\log )$ price level, $y_{t}$ is $(\log )$ income and $i_{t}$ is the interest rate. Hence, the demand for real balances is an increasing function of income, and a decreasing function of the interest rate. The parameters have structural interpretations. $\phi$ is the income elasticity, and $\lambda$ the interest semi-elasticity, of money demand.

Building upon this money demand function, the condition that expected depreciation equals the nominal interest differential (i.e., perfect capital mobility and substitutability), and continuous purchasing power parity one obtains the flexible price monetary model (Frenkel, 1976)

$$
s_{t}=\left(m_{t}-m_{t}^{*}\right)-\phi\left(y_{t}-y_{t}^{*}\right)+\lambda\left(i_{t}-i_{t}^{*}\right)
$$

where $m_{t}$ is the logarithm of the money stock, $y_{t}$ is the log of income, $i_{t}$ is the interest rate and ${ }^{*}$ denotes the local country variable.

The flexible price assumption is undesirable on both theoretical and empirical grounds. One way to relax this assumption is to allow prices to adjust slowly, and monotonically, so as to close the gap between the current and the long run price level. Allowing for secular inflation, the exchange rate behaves as:

$$
s_{t+1}-S_{t}=-\theta\left(s_{t}-\overline{s_{t}}\right)+\left(\Pi_{t}-\Pi_{t}^{*}\right)
$$

where $\Pi_{1}$ is the expected CPI inflation rate from $t$ to $t+1$, and $\Theta$ is the rate of reversion of the price level to its long run value, $\bar{s}$. Equation (10) states that the exchange rate depreciates 
whenever the current exchange rate is stronger than its long run value (denoted by the overbar). Imposing rational expectations, one then obtains the following model due to Frankel (1979) following Dornbusch (1976a)

$$
s_{t}=\left(m_{t}-m_{t}^{*}\right)-\phi\left(y_{t}-y_{t}^{*}\right)-\left(\frac{1}{\theta}\right)\left(i_{t}-i_{t}^{*}\right)+\left(\lambda+\frac{1}{\theta}\right)\left(\Pi_{t}-\Pi_{t}^{*}\right)
$$

The response of the exchange rate to an interest rate decrease is an instantaneous depreciation of the currency. The more rigid prices are, the larger this overshooting effect.

While there is ample reason to doubt the stability of estimated structural models (Meese and Rogoff, 1983a,b), beginning with the work of MacDonald and Taylor (1994), robust evidence of long run relationships has been obtained. In related developments, exchange rates do appear to be related to monetary fundamentals over long horizons. Mark (1995) finds that monetary factors affect exchange rates, while Chinn and Meese (1995) extend this finding to sticky-price monetary models.

\subsection{Modifications to Account for Developing Country Issues}

Because the monetary approach is built on perfect capital mobility and substitutability, it is unreasonable to expect that these models would hold very well for East Asian newly industrializing countries. As is well documented, some of these countries are only now removing restrictions on the capital account, and indeed Korea and Taiwan are still in the process of liberalizing its external accounts (Chinn and Maloney, 1998).

Even in countries with relatively open capital accounts, such as Malaysia and Indonesia, may exhibit covered interest differentials. Woo and Hirayama (1996) argue that the central banks' ability to drastically change monetary policies and financial regulations grants 
them an ability to punish speculators. Consequently, monetary authorities in the region have some short run latitude in manipulating interest rates and independently targeting the exchange rates. Hence, covered interest parity is unlikely to hold. Perfect capital substitutability, defined by Frankel (1983) as the condition where bonds denominated in different currencies are viewed as perfect substitutes, is also ruled out. Summing up, the model's predictions are unlikely to be borne out in the short run because the assumption of uncovered interest rate parity is violated. On the other hand, such deviations will be more difficult to sustain in the long run, so the model's predictions are still of some interest. ${ }^{13}$

Another issue pertains to the stability of the money demand function in equation (8). In LDCs subject to monetization, increasing financial intermediation, or financial repression, a priori assertion of money demand stability is implausible. On the basis of Engle-Granger cointegration tests, Tseng and Corker (1991) assert that a stable cointegrating relationship holds for Indonesia, Korea, Malaysia, Singapore and Thailand. Using the more powerful Johansen (1988) methodology, Dekle and Pradhan (1996) update these results for some Southeast Asian countries and conclude that, with the exception of Indonesia, there is no evidence of real money demand cointegration. ${ }^{14}$ In the Indonesian case, they identify a cointegrating relationship in money demand only after allowing for structural shifts.

Perhaps the most important issue pertains to the relevance of PPP for broad price

\footnotetext{
${ }^{13}$ Time invariant risk premia will be subsumed into the constant of the cointegrating vector.

${ }^{14}$ Dekle and Pradhan (1996) do find that cointegrating relationships hold for nominal money supplies. Further, in the cases of narrow Malaysian, and narrow and broad Thai money, the restriction of homogeneity in price levels cannot be rejected.
} 
indices. The results from Section 2 should suggest the dubious value of this assumption. Because this assumption is so grossly violated empirically in East Asia (Isard and Symansky, 1996; Chinn, 1997c), it is necessary to allow the long run real exchange rate to vary over time.

Following Chinn (1997a), let the log aggregate price index be given as a weighted average of $\log$ price indices of traded $(T)$ and nontraded $(N)$ goods:

$$
p_{t}=(1-\alpha) p_{t}^{T}+\alpha p_{t}^{N}
$$

where $\alpha$ is the share of nontraded goods in the price index. Suppose further that the foreign country's aggregate price index is similarly constructed. Rearranging, and allowing for sticky prices and long run PPP only for tradables prices yields:

$$
\begin{aligned}
s_{t} & =\left(m_{t}-m_{t}^{*}\right)-\phi\left(y_{t}-y_{t}^{*}\right)-\left(\frac{1}{\Theta}\right)\left(i_{t}-i_{t}^{*}\right)+\lambda\left(\Pi_{t}-\Pi_{t}^{*}\right) \\
& +\frac{1}{\Theta}\left(\Pi_{t}^{T}-\Pi_{t}^{T *}\right)-\alpha\left[\left(p_{t}^{N}-p_{t}^{T}\right)-\left(p_{t}^{N *}-p_{t}^{T *}\right)\right]
\end{aligned}
$$

where the price of nontradables (tradables) is proxied by the CPI (PPI).

The relative price variable in square brackets [.] may be determined by any number of factors. In the Balassa (1964) and Samuelson (1964) model, relative prices are driven by relative differentials in productivity in the tradable and nontradable sectors. Relative prices may also be affected by demand side factors. In the long run, the rising preference for services, which are largely nontradable, may induce a secular trend in the relative price of nontradables. Over shorter horizons, government spending on public services may also induce 
changes in relative prices. ${ }^{15}$

In principle, one would like to substitute out for the determinants of the relative price variable in the square brackets, especially since the price of tradables is likely to be endogenous with respect to the exchange rate. Unfortunately, sectoral productivity data is not available at a quarterly frequency for many of the countries being investigated. Hence, I proxy these Balassa-Samuelson and demand side effects with a relative price variable

\subsection{Econometric Methodology}

The current standard in testing for cointegration in time series is the Johansen maximum likelihood estimation technique. Cheung and Lai (1993a), among others, have shown that finite sample critical values may be more appropriate given the relatively small samples which are generally under study. Given the large number of variables (typically nine, or five in relative differences form) and lags of at least one, such finite sample critical values are typically so large as to rule out any opportunity of rejecting the null of no-cointegration Moreover, such maximum likelihood techniques require that the error correction model for each endogenous variable be adequately modeled by the selected specification; this seems a particularly onerous requirement for countries marked by extreme instability in their functional relationships.

In most cases, an error correction model (ECM) is estimated using nonlinear least squares (NLS). Phillips and Loretan (1991) argue that the following NLS estimator is optimal among single-equation estimators:

\footnotetext{
${ }^{15}$ See DeGregorio and Wolf (1994) and Chinn (1997c) among others.
} 


$$
\Delta s_{t}=\gamma_{0}+\Phi_{1}\left(s_{t-1}-\mathrm{B} X_{t-1}\right)+\sum_{i=+1}^{-1} \gamma_{i} \Delta X_{t+i}+u_{t}
$$

where $X$ is a vector of explanatory variables; the specifications include quarterly dummies to account for deterministic seasonality. The leads of the differences of the right hand side variables serve to orthogonalize the error term. If $s$ reacts to the disequilibrium then $\Phi_{1}$ should be negative, and statistically significantly different from zero. This approach, which allows for the possibility of endogenous right hand side variables, is appropriate since many of these East Asian currencies are managed by their central banks. ${ }^{16}$

To check that the residuals are approximately white noise, lags of first differences are added such that the null of no serial correlation cannot be rejected at the $10 \%$ marginal significance level. The F-test version of the Godfrey-Breusch LM test for fourth order serial correlation is used for this purpose.

In cases where the NLS estimator yields very imprecise estimates, I implemented the following two step procedure: first estimate the long run relationship in levels, and second estimate an error correction model (ECM) using the identified cointegrating vector as the error correction term (ECT). The first step is accomplished using the Stock and Watson (1993) dynamic OLS procedure.

$$
s_{t}=\xi_{0}+\mathrm{B} X_{t}+\sum_{i=+2}^{-2} \Xi_{i} \Delta X_{t+i}+v_{t}
$$

where the leads and lags serve to account for endogeneity of the right hand side variables.

${ }^{16}$ For Korea and Taiwan, see Moreno (1996), for Singapore, Moreno and Spiegel (1997). See also Glick and Moreno (1994) 


\subsection{Data}

The analysis is conducted on quarterly data over the period 1974.1 to 1997.4 .

Exchange rates are end-of-period, in US\$/local currency unit. Money is either narrow money (IFS line 34) or broad money (IFS lines 34 plus 35). Income is GDP in 1990 currency units. The exceptions are Taiwan (in 1991 New Taiwan \$).The quarterly Malaysian GDP series spans only a few years so industrial production is used instead of GDP as an income measure. Interest rates are interbank rates. For the Indonesian series, a medium term interest rate is used because the short term rate exhibits several large periods of missing observations which cause a substantial loss of degrees of freedom if used. Inflation rates are calculated as the annual change in the log of the price level, as measured by the CPI.

The relative price variable is calculated as follows:

$$
-\alpha\left[\left(p^{N}-p^{T}\right)-\left(p^{N *}-p^{T *}\right)\right] \approx \omega \equiv \log \left[\frac{\left(P P I^{U S} / C P I^{U S}\right)}{\left(P P I^{*} / C P I^{*}\right)}\right]
$$

The implied long run cointegrating relationship, in terms of observable variables, is then:

$$
s_{t}=\left(m_{t}-m_{t}^{*}\right)-\phi\left(y_{t}-y_{t}^{*}\right)-\left(\frac{1}{\Theta}\right)\left(i_{t}-i_{t}^{*}\right)+\left(\lambda+\frac{1}{\Theta}\right)\left(\Pi_{t+1}-\Pi_{t+1}^{*}\right)+\omega_{t}
$$

A similar specification incorporating a relative price variable is used in Dornbusch (1976b), Clements and Frenkel (1980), Wolff (1987) and Chinn and Meese (1995). (Further details regarding the data are reported in the Data Appendix).

\subsection{Empinical Results}

The most successful regression results from Chinn (1997a) are reported in Table 6. 
Since the focus of interest is on exchange rate determination under floating rates, I omit fixed/pegged period data from each regression (the specific sample periods are indicated in the tables). In certain cases, a time trend is included if it is statistically significant

The simple sticky-price monetary model in equation (11) performs well in two cases: the Thai baht and, to a lesser degree, the Singapore dollar. Hence, for these two currencies, a sticky price monetary model is estimated. Both currencies exhibit significant exchange rate reversion. However, in the latter case, the money stock coefficient is wrongly signed. In both cases, a null hypothesis of a zero coefficient on the $\omega$ coefficient cannot be rejected, while that of unity can. Furthermore, the money variable enters in with near significance only if this relative price variable is omitted. This result is consistent with the finding in Chinn (1997b) that relative prices and relative productivity differentials do not play a role in movements in the baht.

The results of running the regression on equation (17) with narrow money are reported for the other currencies. The Korean, Malaysian, Philippine, Singapore and Taiwanese exchange rates evidence reversion to equilibrium. In all cases money is correctly signed, although the money coefficient is not statistically significant in the Malaysian case. Income coefficients typically show up with statistical insignificance, as do the interest and inflation coefficients. As for the relative price variable, it is correctly signed and significant in the reported cases.

The Korean won is the one currency that best fits the augmented monetary model. The rate of reversion is fairly rapid, implying a half life of a deviation of about 5 quarters. The long run point estimate for money is 0.636 ; one cannot reject the null hypothesis of a unit 
coefficient implied by theory. As for the most important variable, relative prices also enter in positively and significantly; furthermore one cannot reject a unit coefficient. This outcome lends credence to the Bahmani-Oskooee and Rhee (1996) and Chinn (1997c) results showing a role for productivity in the long run real value of the won.

Further discussion of the currencies in which the two step procedure is merited: the Taiwan dollar, Philippine peso and Indonesian rupiah. The Taiwanese relationship is estimated with broad money, allowing for structural breaks. ${ }^{17}$ The exchange rate does not exhibit any significant mean reversion. Additional investigation indicates that the money stock responds to the disequilibrium (although the estimate is not statistically significant) ${ }^{18}$ This outcome is consistent with active targeting of the exchange rate via monetary policy.

A Frenkel specification, augmented by the relative price variable and a time trend yields a plausible set of estimates for the Philippines. Money and relative prices enter significantly. Repeating the two step procedure, I use the implied cointegrating vector as an error correction term. The resulting estimated rate of reversion is 0.560 , suggesting that the Philippine peso does respond strongly to the fundamentals. The only caveat is that the trend term carries a large proportion of weight in the cointegrating vector; extrapolation of this trend effect beyond the sample period is problematic.

${ }^{17}$ Kuo (1990) identifies two periods of liberalization which may have induced some money demand instability. The first predates the beginning of the sample period, and is in any case adjudged ineffectual. The second is dated at November 1983. I incorporate a dummy variable for a level and interaction (with money stock) effect.

${ }^{18}$ The point estimate of -0.06 implies that a half life of a deviation closed by monetary policy is about 4 years (the 2 standard error bounds encompass no reversion, and a one year half life) 
In the case of the Indonesian rupiah, identification of the long run parameters is hampered by the brevity of the floating rate period, and structural breaks in the money demand equation. The two known structural breaks that Dekle and Pradhan (1996) identify in 1983.2 and 1988.3 are econometrically accounted for by indicator variables. ${ }^{19}$ These breaks are associated with liberalization efforts (decontrol of interest rates and opening of the banking sector to new entrants, respectively). In Chinn (1997b) I find that oil prices, along with relative productivity differentials, are an important determinant of Indonesian real exchange rates; one interpretation of this correlation is that the price of oil works through wealth effects. Including the price of oil in the monetary specification, but omitting relative prices, yields the estimates reported in Table 6. The long run coefficients on money and inflation are statistically significant in the negative direction.

I am not able to identify the short run dynamics for the rupiah. The error correction term coefficient in the exchange rate ECM is economically small $(-0.006)$ and statistically insignificant; however a cursory glance at the time series for the rupiah is sufficient to convince one that the monetary authorities were seeking to stabilize the currency around a trend. I find that adjustment takes place through adjustment of Indonesian $M 1$ and of relative prices. The response of this first variable to a disequilibrium is 0.07 . In words, a $1 \%$ deviation induces the central bank to "lean against the wind" by increasing the money stock by $.07 \%$ more than it otherwise would have. However, this point estimate is not statistically significant. Most of the adjustment is borne by the relative price variable $\omega$, which responds very strongly

${ }^{19}$ Dekle and Pradhan (1996) using annual data identify statistical breaks in the cointegrating relationship for the years. The specific quarters correspond to the official implementation of new regulations. 
to a disequilibrium. ${ }^{20}$ This is probably due to the fact that importables play a large role in the price of Indonesian tradables. Consequently, while a long run relationship is identified, the short run dynamics are imprecisely estimated.

It is important to place these statistical results in perspective. In the empirical literature on developed country exchange rate determination, it is commonplace to obtain sign reversals and apparent parameter instability, even after accounting for issues of nonstationarity. Typically, these results are based on quarterly data extending over 23 years of post-Bretton Woods data. In contrast, the results in Table 6 apply to periods as short as seven years (for the Indonesian rupiah) and economies undergoing extremely rapid structural change. Placed against this backdrop the results are fairly impressive.

\subsection{Equilibrium Values}

The models reported in Table 6 are used to generate the equilibrium exchange rates displayed in Figures 20-26. The base year effects are estimated using the sample up to 1994.4. Table 7 reports the implied deviations from equilibrium. As of 1997.1, the Malaysian ringgit, Singapore and Taiwanese dollar and Thai baht are overvalued, although only the Singapore dollar and Taiwanese dollar appear substantially overvalued. Surprisingly, two currencies that experienced the greatest declines -- the Indonesian rupiah and Malaysian ringgit -- are only slightly overvalued, while the Korean won and Philippine peso are undervalued according to this monetary model.

Inspecting the two year average over/undervaluation estimates, one finds the Indonesian rupiah, Thai baht and Taiwan dollar are overvalued, as expected. However, the

${ }^{20}$ The relative price variable responds at a rate of 0.28 per quarter ( $p$-value of .018 ). 
Singapore dollar, which has not experienced as severe a depreciation as the other currencies, is overvalued by $45 \%$ according to the estimated monetary model

The counter-intuitive results could be interpreted as an indictment of the monetary model and its empirical manifestation as a means of judging overvaluation. These results mirror those obtained by Warner (1997) for Mexico who finds that a monetary model yields indicates no currency overvaluation on the eve of the Mexican peso crisis of 1994

\section{CONCLUSIONS}

This paper has discussed the implementation of two major approaches to judging overand undervaluation. By far, the most ambitious uses a model-based criterion, incorporating monetary and real factors. Unfortunately, these results do not match up with prior expectations very well. The most likely reason for this outcome is that the calculation of model-based equilibrium values requires the estimation of a much larger number of parameters, thereby introducing more possibilities of making substantial errors. In contrast, the PPP based calculations, which are simpler to generate, are suggestive of overvaluation of the anticipated nature. The use of the PPP criterion is justified by the finding of real exchange rate mean-stationarity, when real exchange rates are defined using a price index of tradable goods. Admittedly, however, the implied currency overvaluations of appear small -- although admittedly persistent -- when placed against the magnitudes of the subsequent currency crashes.

The hazards of using CPI-based real exchange rates in conjunction with deterministic trends are illustrated by the results in Table 5. The CPI measures indicate a $13 \%$ 
overvaluation of the Singapore dollar, on par with the Thai baht and Malaysian ringgit; yet the Singapore dollar fell substantially less. The PPI based measures, in this context, provided superior predictions. Furthermore, since the CPI-deflated real exchange rates do not appear to be trend stationary, it is difficult to ascribe an economic interpretation to deviations from the trend

Finally, a full assessment of currency overvaluation probably cannot be undertaken on a purely bilateral basis. Future research should address the manner in which one should construct multilateral exchange rate indices, with special reference to the role of China. 


\section{References}

Bahmani-Oskooee, Mohsen, 1993, "Purchasing Power Parity Base on Effective Exchange Rates and Cointegration: 25 LDCs Experience with Its Absolute Formulation," World Development 21(6): 1023-31.

Bahmani-Oskooee, Mohsen, and Hyun-Jae Rhee, 1996, "Time-Series Support for Balassa's Productivity-Bias Hypothesis: Evidence from Korea," Review of Intemational Economics 4 : 364-370.

Balassa, Bela, 1964, "The Purchasing Power Parity Doctrine: A Reappraisal," Joumal of Political Economy 72: 584-596.

Bayoumi, Tamim, Peter Clark, Steve Symansky and Mark Taylor, 1994, "The Robustness of Equilibrium Exchange Rate Calculations to Alternative Assumptions and Methodologies," in John Williamson (ed.), Estimating Equilibrium Exchange Rates (Washington, DC: Institute for International Economics): 19-60.

Breuer, Janice Boucher, 1994, "An Assessment of the Evidence on Purchasing Power Parity," in John Williamson (ed.), Estimating Equilibrium Exchange Rates (Washington, DC: Institute for International Economics): 245-277.

Canzoneri, Matthew, Robert Cumby and Behzad Diba, 1996, "Relative Labor Productivity and the Real Exchange Rate in the Long Run: Evidence for a Panel of OECD Countries," NBER Working Paper \#5676.

Cheung, Yin-Wong and Kon. S. Lai, 1996, "Parity Reversion in Real Exchange Rates during the Post-Bretton Woods Period," Working Paper \#348 (Department of Economics, University of California: Santa Cruz).

Cheung, Yin-Wong and Kon. S. Lai, 1993a, "Finite-Sample Sizes of Johansen's Likelihood Ratio Tests for Cointegration," Oxford Bulletin of Economics and Statistics 55(3): 313-328

Cheung, Yin-Wong and Kon. S. Lai, 1993b, "Long-Run Purchasing Power Parity during the Recent Float," Joumal of International Economics 34: 181-92.

Chinn, Menzie, 1998, Estimating East Asian Currency Overvaluation," Mimeo (Department of Economics, University of California: Santa Cruz, January).

Chinn, Menzie, 1997a, "On the Won and Other East Asian Currencies," Pacific Basin Discussion Paper PB97-07 (Federal Reserve Bank of San Francisco).

Chinn, Menzie, 1997b, "Paper Pushers or Paper Money? Empirical Assessment of Fiscal and Monetary Models of Exchange Rate Determination." Journal of Policy Modeling 19(1): 51- 
Chinn, Menzie, 1997c, "The Usual Suspects: Productivity and Demand Shocks and AsiaPacific Real Exchange Rates," NBER Working Paper \#6108.

Chinn, Menzie and Michael Dooley, 1997, "Asia-Pacific Capital Markets: Measurement of Integration and the Implications for Economic Activity,"in T. Ito and A.O. Krueger (editors) Regionalism versus Multilateral Trading Arrangement (Chicago U. Press for NBER: Chicago), pp. 169-196.

Chinn, Menzie and William Maloney, 1998, "Financial and Capital Account Liberalization in the Pacific Basin: Korea and Taiwan." Intemational Economic Joumal 12(1) (Spring): 1-22.

Chinn, Menzie and Richard Meese, 1995, "Banking on Currency Forecasts: Is Change in Money Predictable?" Joumal of Intemational Economics 38 (1-2): 161-78.

Clements, Kenneth and Jacob Frenkel, 1980, "Exchange Rates, Money, and Relative Prices: The Dollar-Pound in the 1920's," Joumal of Intemational Economics 10: 249-62

DeGregorio, Jose and Holger Wolf, 1994, "Terms of Trade, Productivity, and the Real Exchange Rate," NBER Working Paper \#4807 (July).

Dekle, Robert, and Mahmood Pradhan, 1996, "Financial Liberalization and Money Demand in ASEAN Countries: Implications for Monetary Policy," paper presented at conference on "Macroeconomic Issues Facing ASEAN", Jakarta, November 7-8, 1996.

Dooley, Michael, 1997, "A Model of Crises in Emerging Markets," Mimeo (October).

Dornbusch, Rudiger, 1976a, "Expectations and Exchange Rate Dynamics," Joumal of Political Economy 84: 1161-1176.

Dornbusch, Rudiger, 1976b, "The Theory of Flexible Exchange Rate Regimes and Macroeconomic Policy." in Jacob Frenkel and Harry Johnson (eds.) The Economics of Exchange Rates (Reading, MA: Addison-Wesley).

Dornbusch, Rudiger, Ilan Goldfajn and Rodrigo Valdes, 1995, "Currency Crises and Collapses," Brookings Papers on Economic Activity 1995 (2): 219-70.

Driver, Rebecca and Simon Wren-Lewis, 1996, "How Robust Are FEERs? Paper presented at the conference "Equilibrium Exchange Rates" organized by Ronald MacDonald, Strathclyde University (Glasgow, UK), December 6th, 1996.

Engel, Charles, 1995, "Accounting for US Real Exchange Rate Changes," NBER Working Paper \#5394. 
Frankel, Jeffrey, 1979, "On the Mark: A Theory of Floating Exchange Rates Based on Real Interest Differentials," American Economic Review 69: 610-622

Frankel, Jeffrey A., 1983, "Monetary and Portfolio Balance Models of Exchange Rate Determination," in J.S. Bhandari and B. Putnam (eds.) Economic Interdependence and Flexible Exchange Rates, MIT Press: 84-115.

Frankel, Jeffrey and Andrew Rose, 1996, "A Panel Project on Purchasing Power Parity: Mean Reversion within and between Countries," Joumal of Intermational Economics 40(1/2): 209224.

Frenkel, Jacob A., 1976, "A Monetary Approach to the Exchange Rate: Doctrinal Aspects and Empirical Evidence," Scandinavian Joumal of Economics 78: 200-224.

Glick, Reuven and Ramon Moreno, 1994, "Capital Flows and Monetary Policy in East Asia," in Hong Kong Monetary Authority (editor) Monetary and Exchange Rate Management with International Capital Mobility (Hong Kong: Hong Kong Monetary Authority).

Goldfajn, Ilan and Rodrigo Valdes, 1995, "The Aftermath of Appreciations," NBER Working Paper \#5650.

Horvath, Michael and Mark Watson, 1995, "Testing for Cointegration when Some of the Cointegrating Vectors Are Prespecified," Econometric Theory 11: 984-1014.

Huh, Chan and Kenneth Kasa, 1997, "A Dynamic Model of Export Competition, Policy Coordination and Simultaneous Currency Collapse," Pacific Basin Working Paper PB97-08 (Federal Reserve Bank of San Francisco).

Isard, Peter and Steven Symansky, 1996, "Long Run Movements in Real Exchange Rates," Chapter 2 in Takatoshi Ito, Peter Isard, Steven Symansky and Tamim Bayoumi, Exchange Rate Movements and Their Impact on Trade and Investment in the APEC Region, Occasional Paper 145 (Washington, DC: International Monetary Fund, December).

Ito, Takatoshi, Peter Isard and Steven Symansky, 1996, "Economic Growth and Real Exchange Rate: An Overview of the Balassa-Samuelson Hypothesis in Asia," paper presented at the Seventh Annual NBER-EASE Conference "Changes in Exchange Rates in Rapidly Developing Countries: Theory, Practice, and Policy Issues," Hong Kong, June 19-22, 1996.

Johansen, Søren, 1988, "Statistical Analysis of Cointegrating Vectors," Journal of Economic Dynamics and Control 12: 231-54.

Johansen, Søren, and Katerina Juselius, 1990, "Maximum Likelihood Estimation and Inference on Cointegration - With Applications to the Demand for Money," Oxford Bulletin of Economics and Statistics 52: 169-210. 
Jorion, Philippe and Richard Sweeney, 1996, "Mean Reversion in Real Exchange Rates:

Evidence and Implications for Forecasting," Joumal of International Money and Finance 15

(4): $535-550$.

Kremers, Jeroen, Neil Ericsson and Juan Dolado, 1992, "The Power of Cointegration Tests," Oxford Bulletin of Economics and Statistics 54(3): 325-48.

Kuo, Shirley W.Y., 1990, "Liberalization of the Financial Market in Taiwan in the 1980's," Pacific-Basin Capital Markets Research 1: 7-26.

MacDonald, Ronald, 1995, "Long-Run Exchange Rate Modeling - A Survey of the Recent Evidence," International Monetary Fund Staff Papers 42(3):437-489.

MacDonald, Ronald, and Mark Taylor, 1994, "The Monetary Model of the Exchange Rate: Long-Run Relationships, Short-Run Dynamics and How to Beat a Random Walk," Joumal of International Money and Finance 13(3):276-290.

Mark, Nelson, 1995, "Exchange Rates and Fundamentals: Evidence on Long-Horizon Predictability," American Economic Review 85(1): 201-218.

Milesi-Ferretti, Gian Maria and Assaf Razin, 1996, "Current Account Sustainability: Selected East Asian and Latin American Experiences," NBER Working Paper \#5791.

Moreno, Ramon, 1996, "Intervention, Sterilization, and Monetary Control in Korea and Taiwan," Federal Reserve Bank of San Francisco Economic Review (3): 23-33

Moreno, Ramon, 1988, "Exchange Rates and Monetary Policy in Singapore and Hong Kong," in Hang-Sheng Cheng (editor), Monetary Policy in Pacific Basin Countries, (Boston: Kluwer), pp. $173-200$.

Moreno, Ramon and Mark Spiegel, 1997, "Are Asian Economies Exempt from the 'Impossible Trinity': Evidence from Singapore," Pacific Basin Working Paper Series PB97-01 (Federal Reserve Bank of San Francisco).

Oh, Keun-Yeob, 1996, "Purchasing power parity and unit root tests using panel data," Journal of International Money and Finance 15 (3): 405-418

Phillips, Peter C.B. and Mico Loretan, 1991, "Estimating Long-run Equilibria," Review of Economic Studies 58: 407-436.

Phylaktis, Kate and Yiannis Kassimatis, 1994, "Does the Real Exchange Rate Follow a Random Walk? The Pacific Basin Perspective," Joumal of Intemational Money \& Finance 13(4) (August):476-495. 
Rotemberg, Julio and Garth Saloner, 1986, "A Supergame-Theoretic Model of Price Wars during Booms," American Economic Review 76: 390-407.

Samuelson, Paul, 1964, "Theoretical Notes on Trade Problems," Review of Economics and Statistics 46: 145-154.

Stock, James, and Mark Watson, 1993,"A Simple Estimator of Cointegrating Vectors in Higher Order Integrated Systems, Econometrica 61: 783-820.

Tang, Min and Ronald Q. Butiong, 1994, Purchasing Power Parity in A sian Developing Countries: A Cointegration Test, Statistical Report Series \#17 (Manila: Asian Development Bank, April).

Tseng, Wanda and Robert Corker, 1991, "Financial Liberalization, Money Demand, and Monetary Policy in A sian Countries, Occasional Paper 84, Washington, DC:IMF, 1991.

Wolff, Christian C.P., 1987,"Time-Varying Parameters and the Out-of-Sample Forecasting Performance of Structural Exchange Rate Models," Joumal of Business and Economic Statistics 5(1): 87-97.

Warner, Andrew, 1997, "Mexico's 1994 Exchange Rate Crisis Interpreted in Light of the NonTraded Model," NBER Working Paper \#6165.

Williamson, John (editor), Estimating Equilibrium Exchange Rates (Washington, DC: Inst. International Economics)

Woo, Wing Thye and Kenjiro Hirayama, 1996, "Monetary Autonomy in the Presence of Capital Flows: And Never the Twain Shall Meet, Except in East Asia?" in T. Ito and A.O Krueger (eds.) Financial Deregulation and Integration in East A sia (U. Chicago Press).

World Financial Markets, 1993, (New York: Morgan Guaranty, Nov. 19).

Wu, Yangru, 1996, "Are Real Exchange Rates Nonstationary? Evidence from a Panel Data Test," Joumal of Money, Credit and Banking 28 (1):54-63. 


\section{Data Appendix}

The data are from IMF, Intemational Financial Statistics, November 1997 CD-ROM, except for data for Taiwan: Bank of China, Financial Statistics, various issues, as recorded in Federal Reserve Bank of San Francisco electronic database.

\section{Section 2: Monthly Data}

Exchange rates, IFS line ae, in US\$/local currency unit, end of period.

Consumer price index, IFS line 64, $1990=100$.

$\square$ Producer price index, IFS line 63, $1990=100$. Indonesian data excludes petroleum prices. Hong Kong data is quarterly, starting from 1991.1 (Source: Hong Kong Department of Census and Statistics, personal communication from Winnie Tam).

$\square$ Export price index, IFS line 74, $1990=100$.

"Broad" trade-weighted real exchange rates (PPI-deflated). 1990=100, 1990 trade weights for 1987-97; 1980 trade weights for 1970-86. Hong Kong series adjusted by Hong Kong retail price index (Source: Morgan Guaranty, http://www.jpmorgan com).

$\square$ Chinese monthly CPI. Estimated using annual inflation rates added to a 12 month centered moving average of annual CPIs.

\section{Section 3: Quarterty Data}

Exchange rates, IFS line ae, in US\$/local currency unit, end of period.

$\square$ Narrow money, IFS line 34, in national currency units. Broad money is narrow money plus quasi- money IFS line 35 , in national currency units.

$\square$ Income is real GDP, IFS line 99b.r, in 1990 national currency units. Malaysia income is proxied by industrial production. Taiwanese GDP, in 1991 New Taiwan dollar. For Indonesia, and Singapore, GDP data is a centered 4 quarter moving average of annual data. Interpolation is via the formula:

$$
\begin{aligned}
y_{\tau, Q 1} & =.375 \times y_{\tau-1}+.625 \times y_{\tau} \\
y_{\tau, Q 2} & =.125 \times y_{\tau-1}+.875 \times y_{\tau} \\
y_{\tau, Q 3} & =.875 \times y_{\tau}+.125 \times y_{\tau+1} \\
y_{\tau, Q 4} & =.625 \times y_{\tau}+.375 \times y_{\tau+1} \\
\text { for } \tau & =1971, . ., 1997
\end{aligned}
$$

Interest rates are short term, interbank interest rates, IFS line $60 \mathrm{~b}$, in decimal form. Indonesian interest rates are long term, from Morgan Guaranty database. Missing values interpolated using an estimated AR(1).

$\square$ Consumer price index, IFS line 64, $1990=100$.

$\square$ Producer price index, IFS line 63,1990 = 100. Indonesian data excludes petroleum prices (IFS (line 63a.

$\square$ Inflation is 4-quarter difference of $\log (\mathrm{CPI})$.

$\square$ Relative price variable: 


$$
-\alpha\left[\left(p^{N}-p^{T}\right)-\left(p^{N *}-p^{T *}\right)\right] \approx \omega \equiv \log \left(P P I^{U S} / C P I^{U S}\right)-\log \left(P P I^{*} / C P I^{*}\right)
$$

[which is appropriate if $\alpha=0.5$, and CPI contains one half nontradables]. 
Table 1

Monthly Drift Terms of Real Exchange Rates

1975.01-1996.12

\begin{tabular}{|c|c|c|c|c|c|c|c|}
\hline & \multicolumn{2}{|l|}{ CPI } & \multicolumn{3}{|c|}{$\begin{array}{l}\text { PPI } \\
-\end{array}$} & \multicolumn{2}{|c|}{ Export Prices } \\
\hline & $\$$ & $¥$ & ROW & $\$$ & $¥$ & $\$$ & $¥$ \\
\hline HK & $\begin{array}{l}0.0044 * \star \star a / \\
(0.0006)\end{array}$ & $\begin{array}{l}0.0034 \\
(0.0036)\end{array}$ & $\begin{array}{l}0.0000 \\
(0.0172)\end{array}$ & $\begin{array}{l}-0.0000 \mathrm{~b} \\
(0.0001)\end{array}$ & $\begin{array}{c}-0.0004 \mathrm{E} \\
(0.0040)\end{array}$ & $\begin{array}{l}-0.0005 \subseteq \\
(0.0010)\end{array}$ & $\begin{array}{c}-0.0016 \mathrm{c} \\
(0.0023)\end{array}$ \\
\hline IN & $\begin{array}{l}-0.0029 \\
(0.0024)\end{array}$ & $\begin{array}{c}-0.0047 * \\
(0.0029)\end{array}$ & $\begin{array}{l}-0.0019 \\
(0.0019)\end{array}$ & $\begin{array}{l}-0.0006 \\
(0.0023)\end{array}$ & $\begin{array}{l}-0.0015 \\
(0.0027)\end{array}$ & $\begin{array}{l}-0.0095 \\
(0.0067)\end{array}$ & $\begin{array}{l}-0.0100 \\
(0.0070)\end{array}$ \\
\hline KO & $\begin{array}{l}0.0009 \\
(0.0009)\end{array}$ & $\begin{array}{l}-0.0009 \\
(0.0022)\end{array}$ & $\begin{array}{l}-0.0008 \\
(0.0009)\end{array}$ & $\begin{array}{l}0.0003 \\
(0.0010)\end{array}$ & $\begin{array}{l}-0.0006 \\
(0.0021)\end{array}$ & $\begin{array}{c}-0.0036^{\star} \star \\
(0.0017)\end{array}$ & $\begin{array}{l}-0.0051 \\
(0.0037)\end{array}$ \\
\hline MA & $\begin{array}{c}-0.0015 \star \\
(0.0009)\end{array}$ & $\begin{array}{c}-0.0034 * \\
(0.0019)\end{array}$ & $\begin{array}{l}-0.0010 \\
(0.0009)\end{array}$ & $\begin{array}{l}0.0004 \\
(0.0013)\end{array}$ & $\begin{array}{l}-0.0008 \\
(0.0027)\end{array}$ & $\begin{array}{l}-0.0030 \\
(0.0033)\end{array}$ & $\begin{array}{l}-0.0031 \\
(0.0037)\end{array}$ \\
\hline PH & $\begin{array}{l}0.0002 \\
(0.0018)\end{array}$ & $\begin{array}{l}-0.0017 \\
(0.0029)\end{array}$ & $\begin{array}{l}0.0007 \\
(0.0016)\end{array}$ & $\begin{array}{l}0.0011 \\
(0.0017)\end{array}$ & $\begin{array}{l}0.0002 \\
(0.0027)\end{array}$ & $\begin{array}{l}-0.0039 \\
(0.0055)\end{array}$ & $\begin{array}{l}-0.0043 \\
(0.0059)\end{array}$ \\
\hline SI & $\begin{array}{l}-0.0003 \\
(0.0009)\end{array}$ & $\begin{array}{l}-0.0021 \\
(0.0018)\end{array}$ & $\begin{array}{l}-0.0009 \\
(0.0010)\end{array}$ & $\begin{array}{l}-0.0005 \\
(0.0012)\end{array}$ & $\begin{array}{l}-0.0012 \\
(0.0019)\end{array}$ & $\begin{array}{l}0.0013 \\
(0.0020)\end{array}$ & $\begin{array}{l}0.0007 \\
(0.0027)\end{array}$ \\
\hline $\mathrm{TH}$ & $\begin{array}{l}-0.0004 \\
(0.0009)\end{array}$ & $\begin{array}{l}-0.0023 \\
(0.0020)\end{array}$ & $\begin{array}{l}-0.0006 \\
(0.0010)\end{array}$ & $\begin{array}{l}-0.0001 \\
(0.0010)\end{array}$ & $\begin{array}{l}-0.0010 \\
(0.0019)\end{array}$ & $\begin{array}{l}-0.0006 \\
(0.0018)\end{array}$ & $\begin{array}{c}-0.0005 \\
(0.0028)\end{array}$ \\
\hline TI & $\begin{array}{l}0.0009 \\
(0.0010)\end{array}$ & $\begin{array}{l}-0.0005 \\
(0.0023)\end{array}$ & $\begin{array}{l}-0.0004 \\
(0.0008)\end{array}$ & $\begin{array}{l}-0.0000 \\
(0.0008)\end{array}$ & $\begin{array}{l}-0.0009 \\
(0.0021)\end{array}$ & & \\
\hline JP & $\begin{array}{l}0.0018 \\
(0.0021)\end{array}$ & & $\begin{array}{l}0.0004 \\
(0.0013)\end{array}$ & $\begin{array}{l}0.0009 \\
(0.0020)\end{array}$ & & $\begin{array}{l}0.0003 \\
(0.0023)\end{array}$ & \\
\hline
\end{tabular}

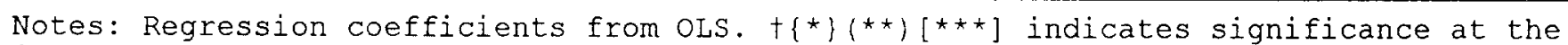
$20 \%\{10 \%\}(5 \%)[1 \%$ MSL.

at Sample period 1990.01 to 1996.12 .

b/ Sample period 1991.1 to 1996.4 converted to monthly basis.

g) Sample period 1985.01 to 1996.12 . 


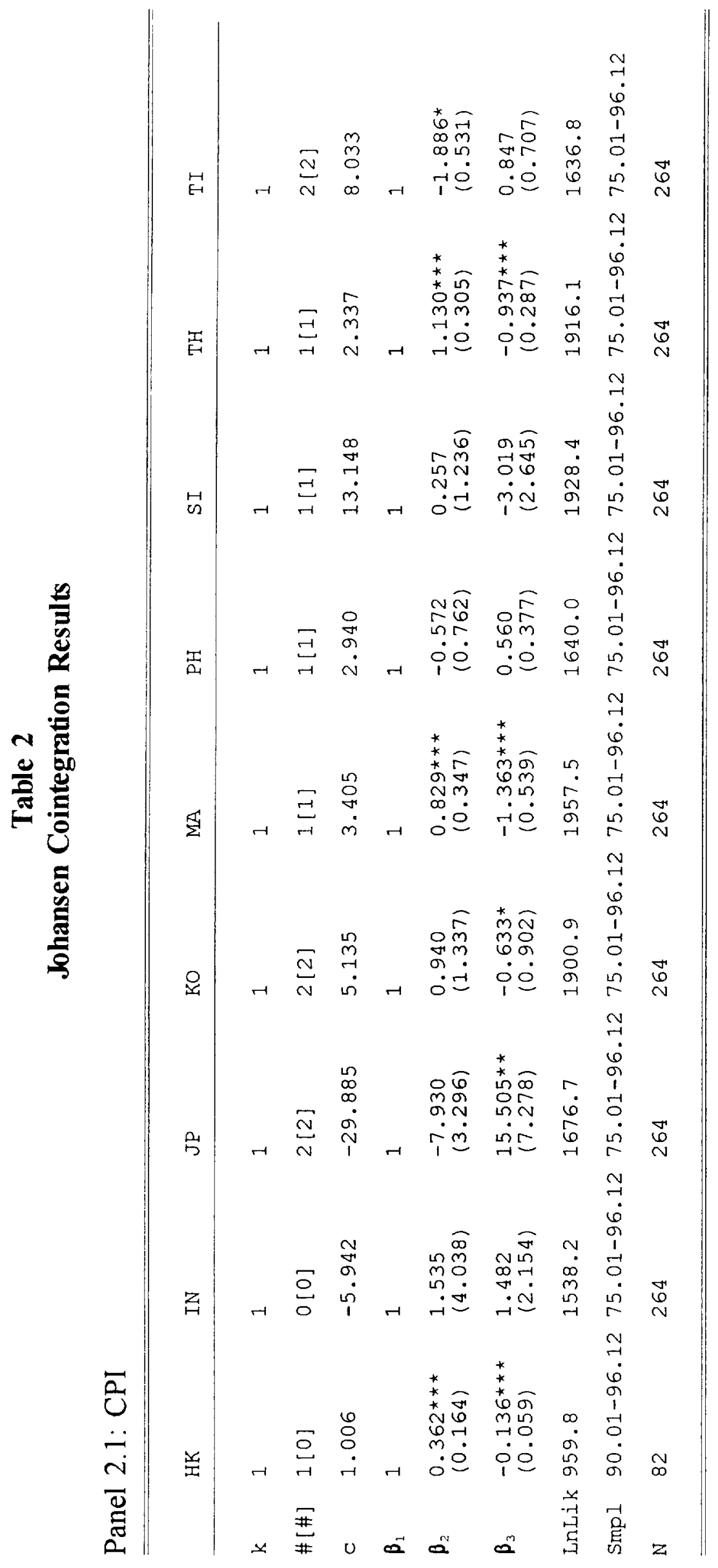

n 


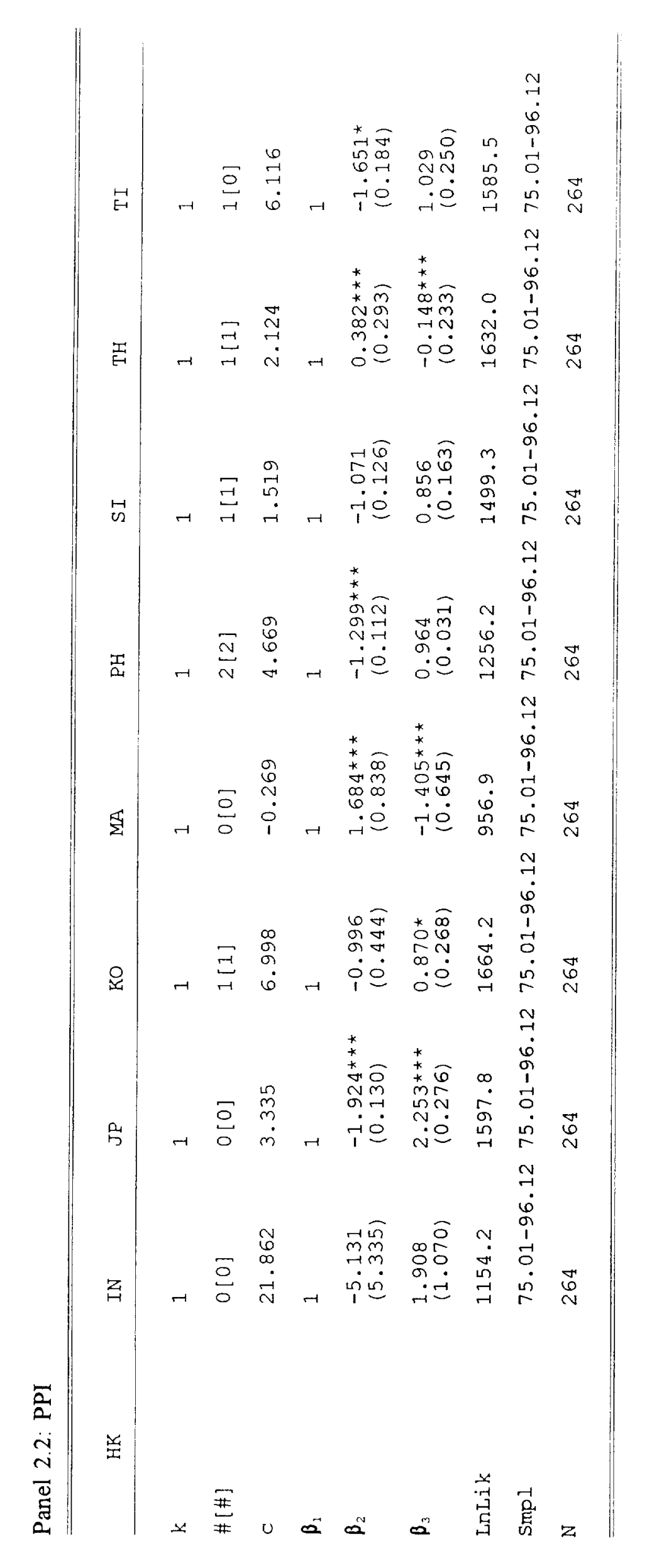




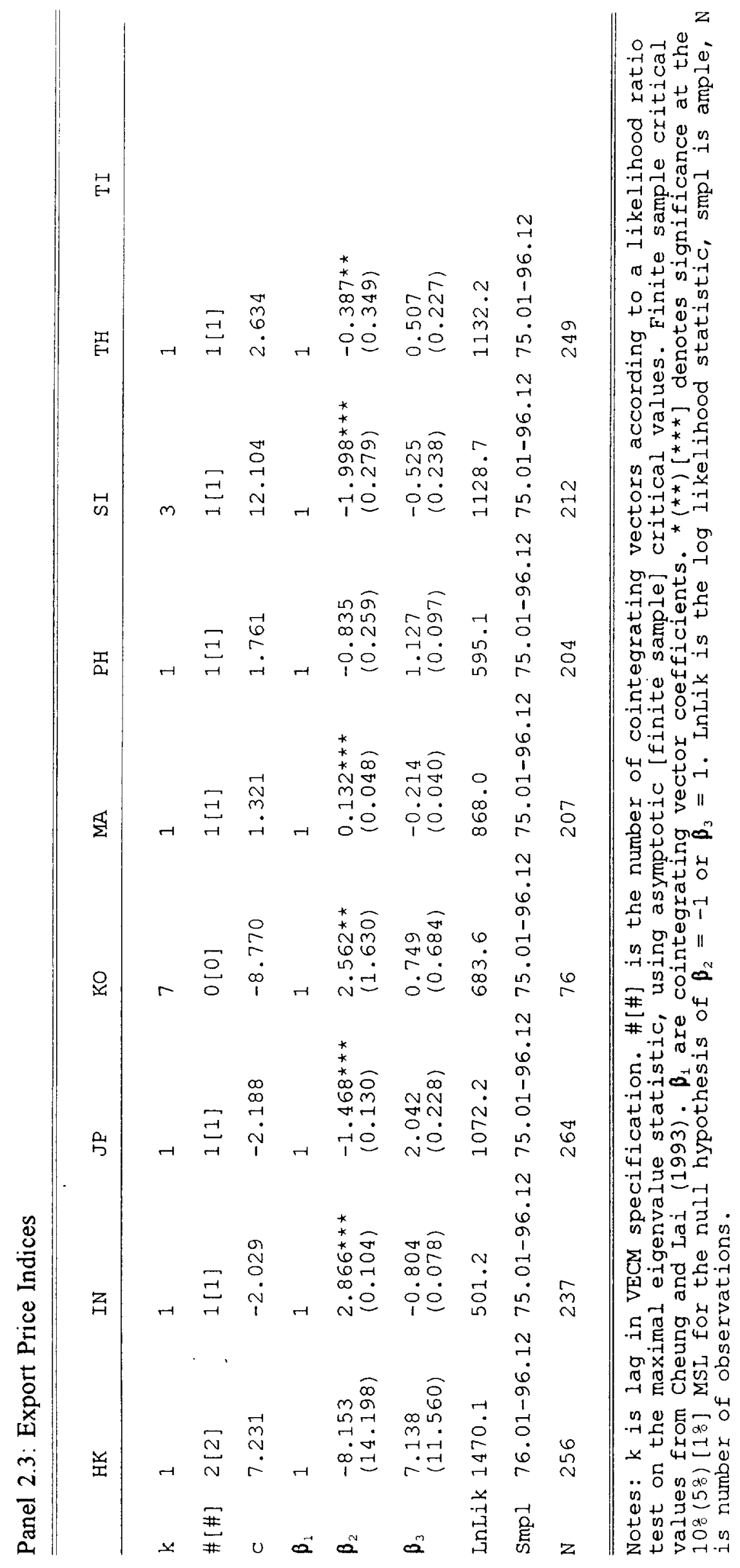




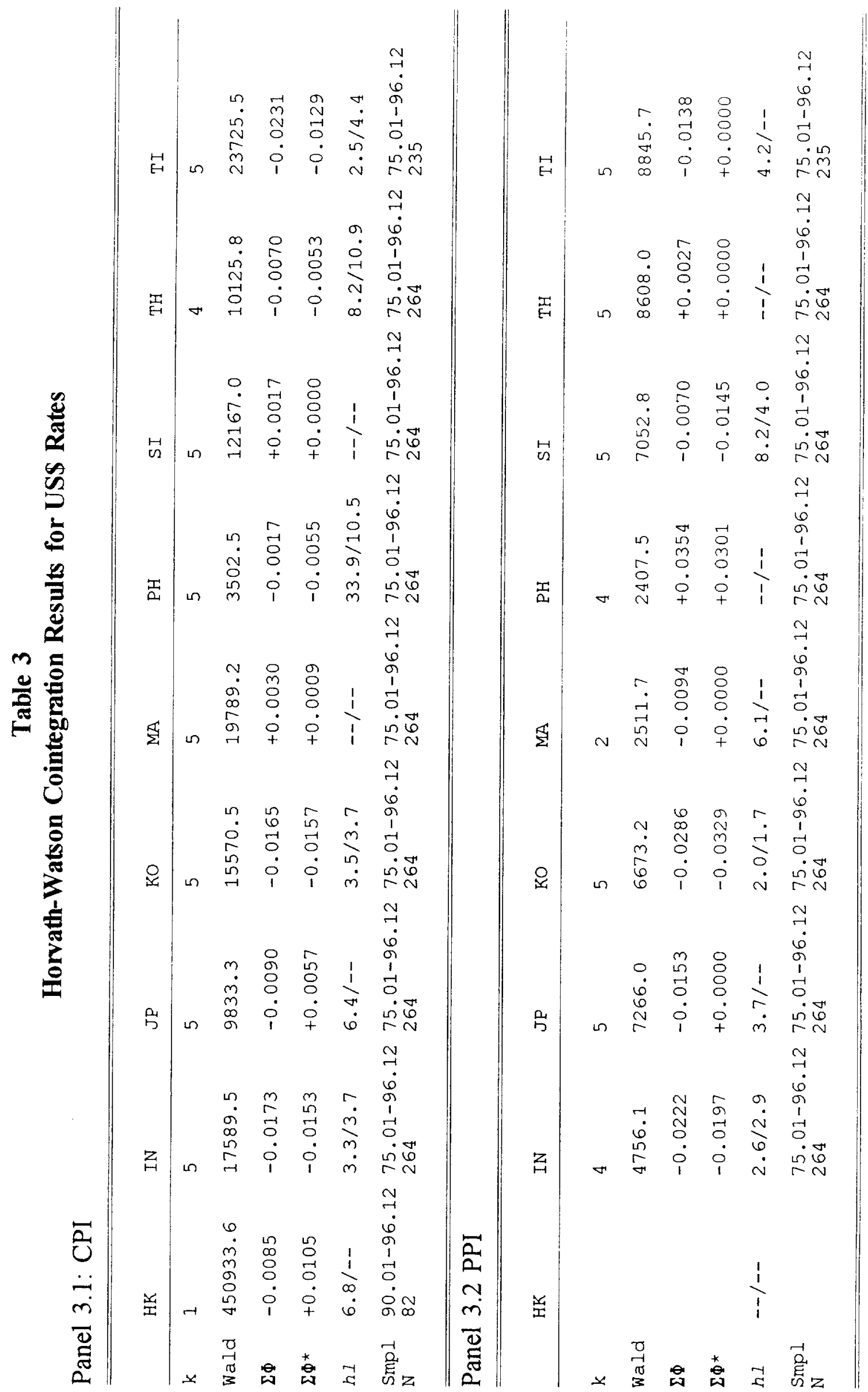




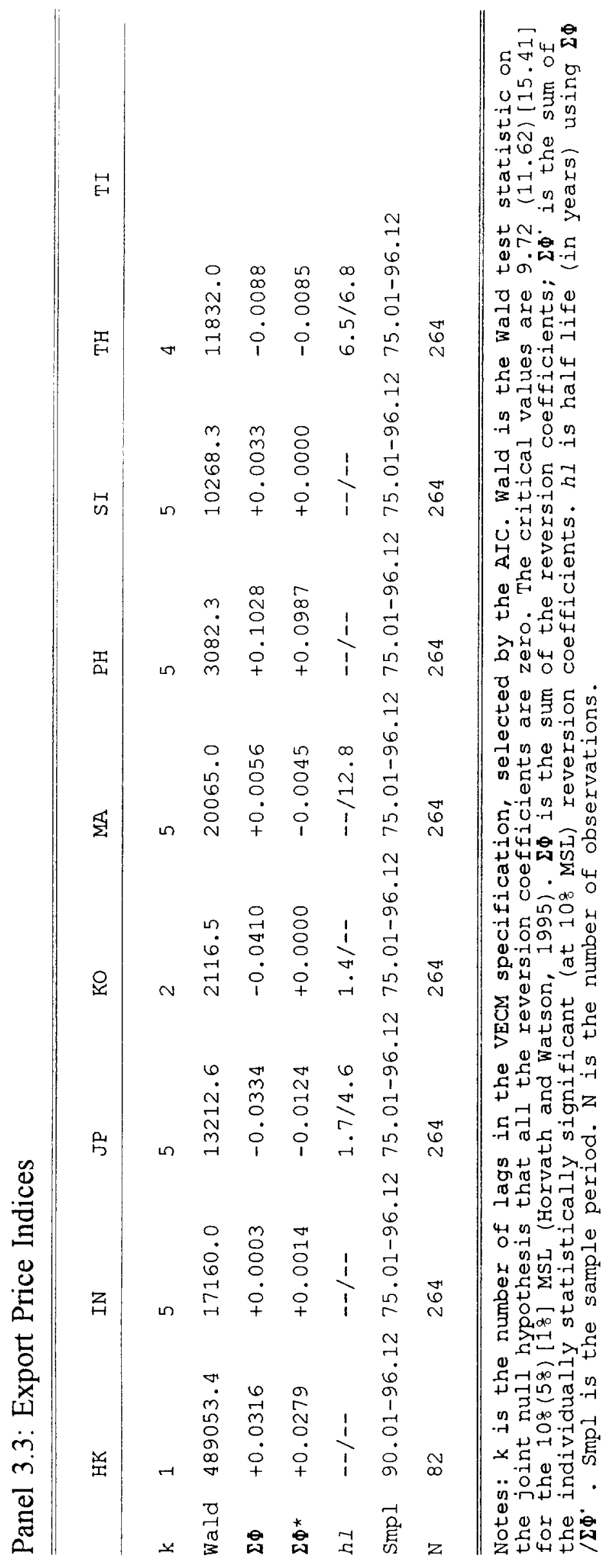




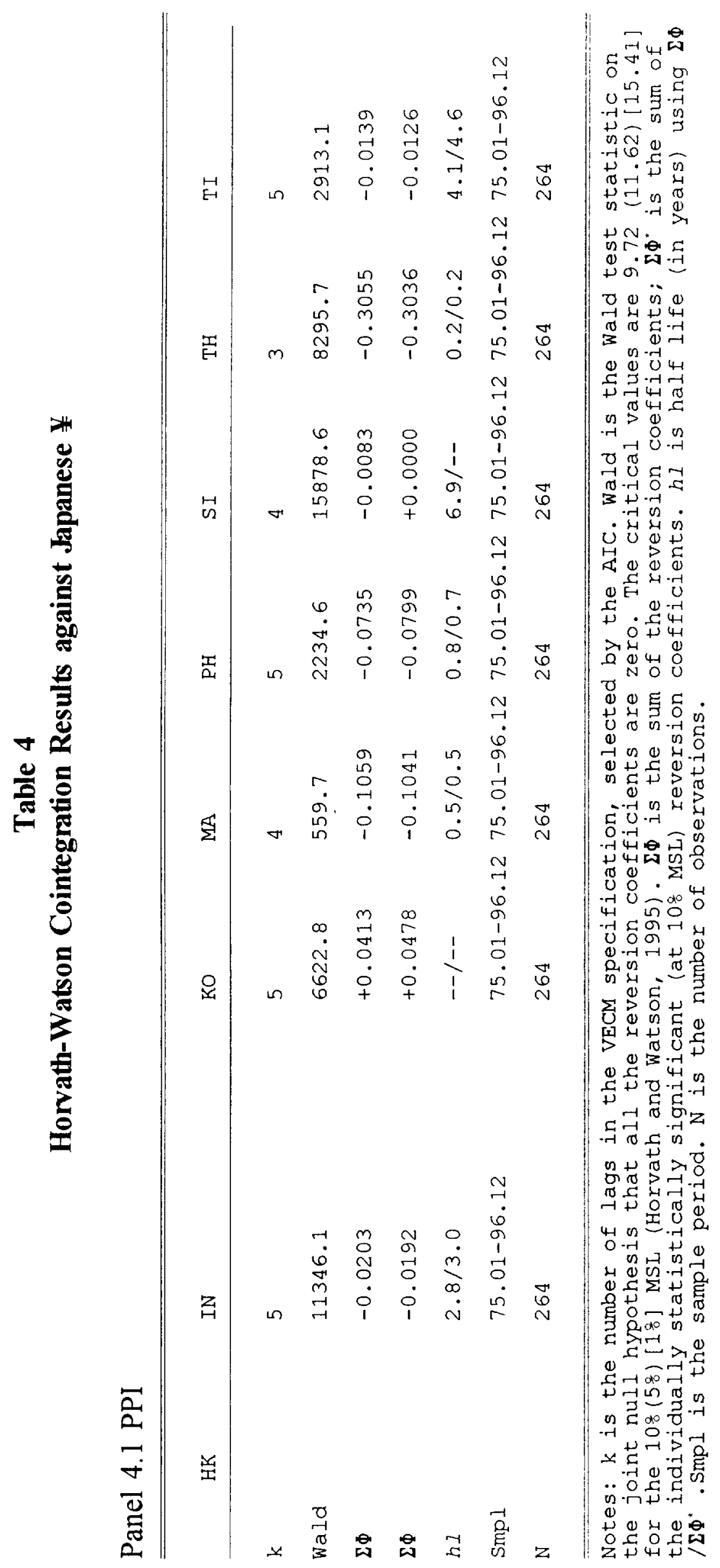




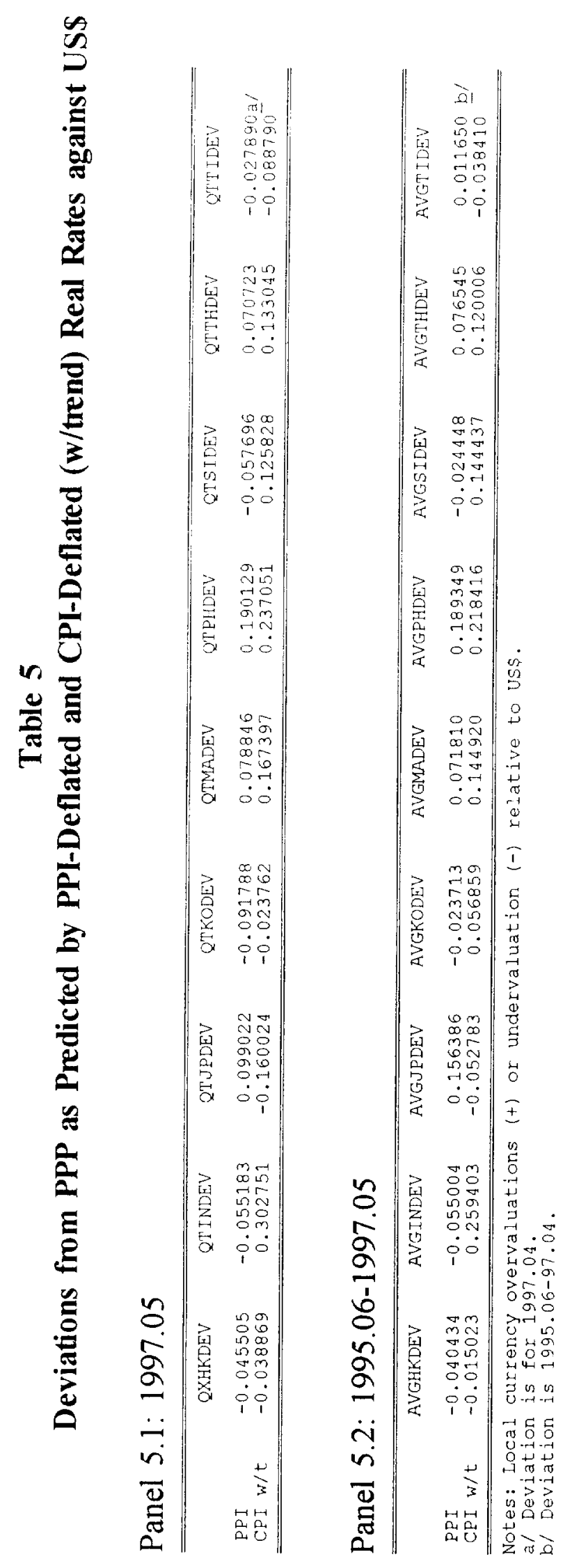




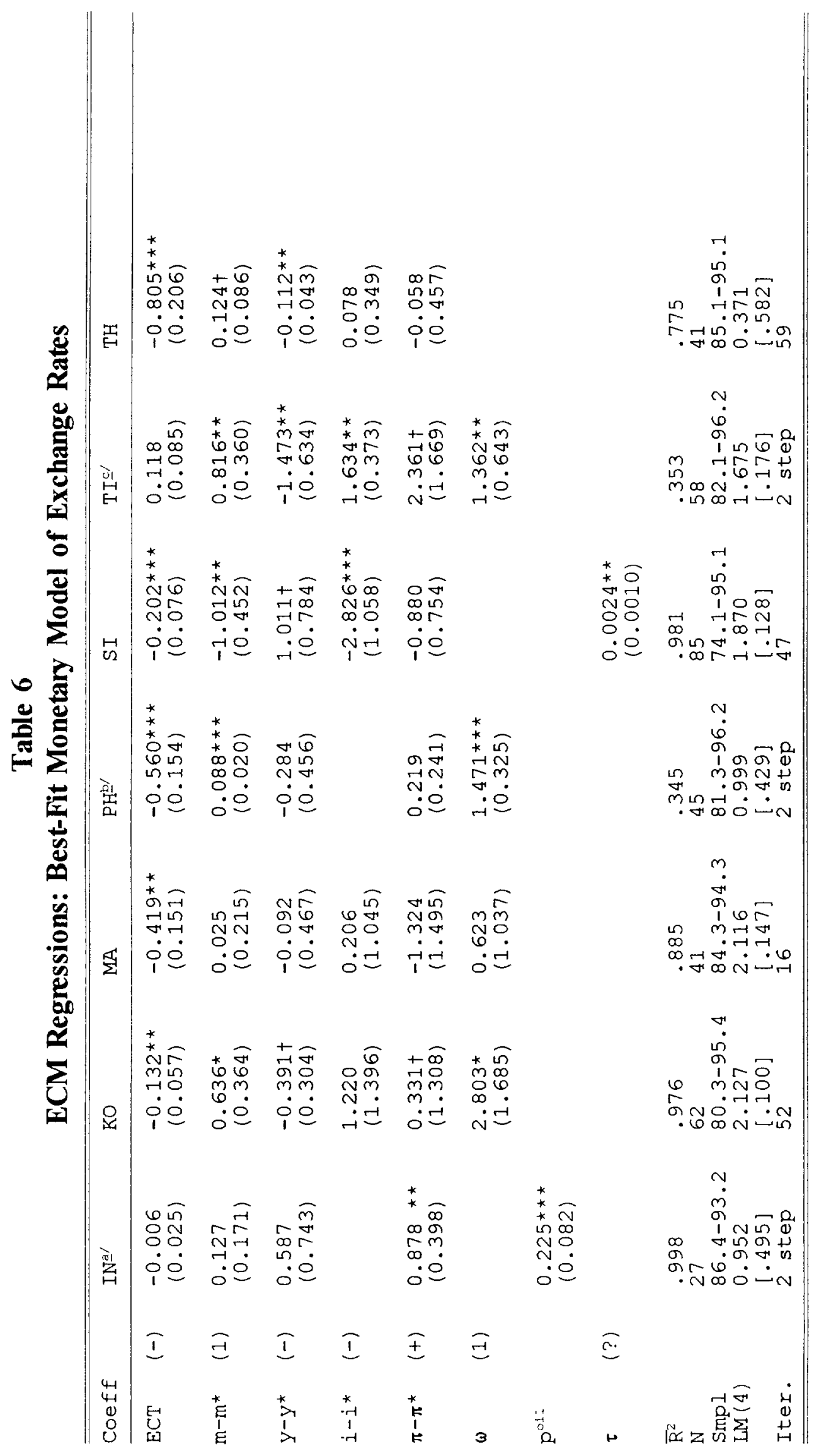




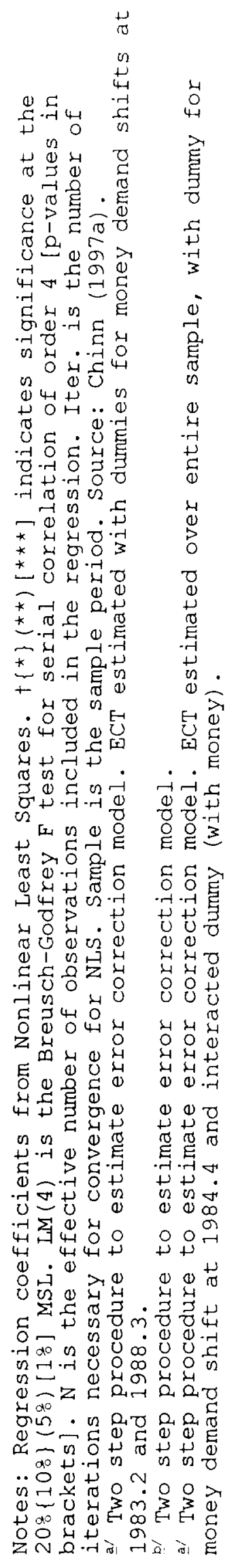




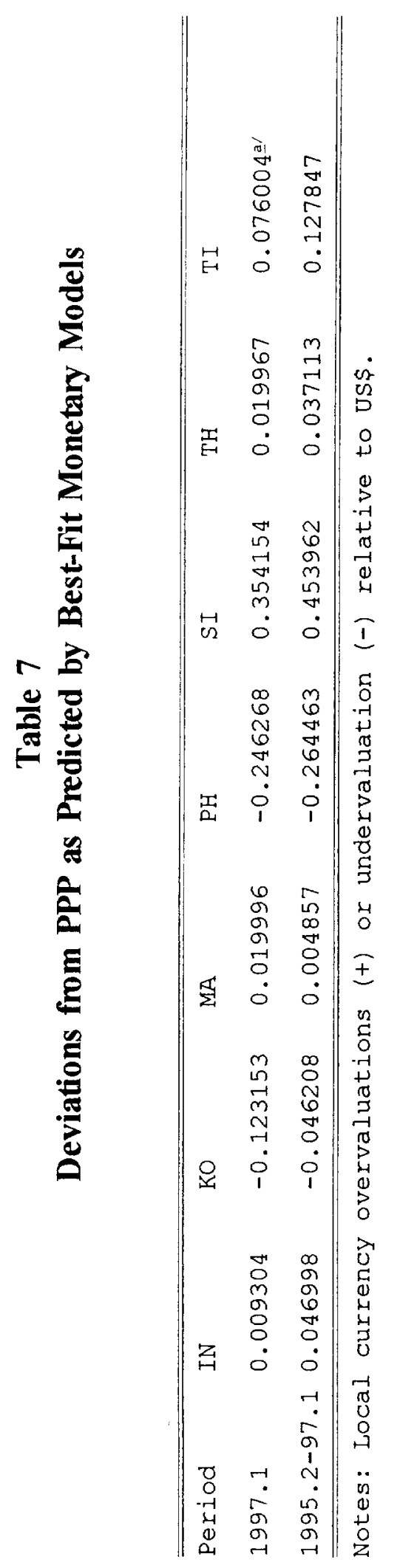




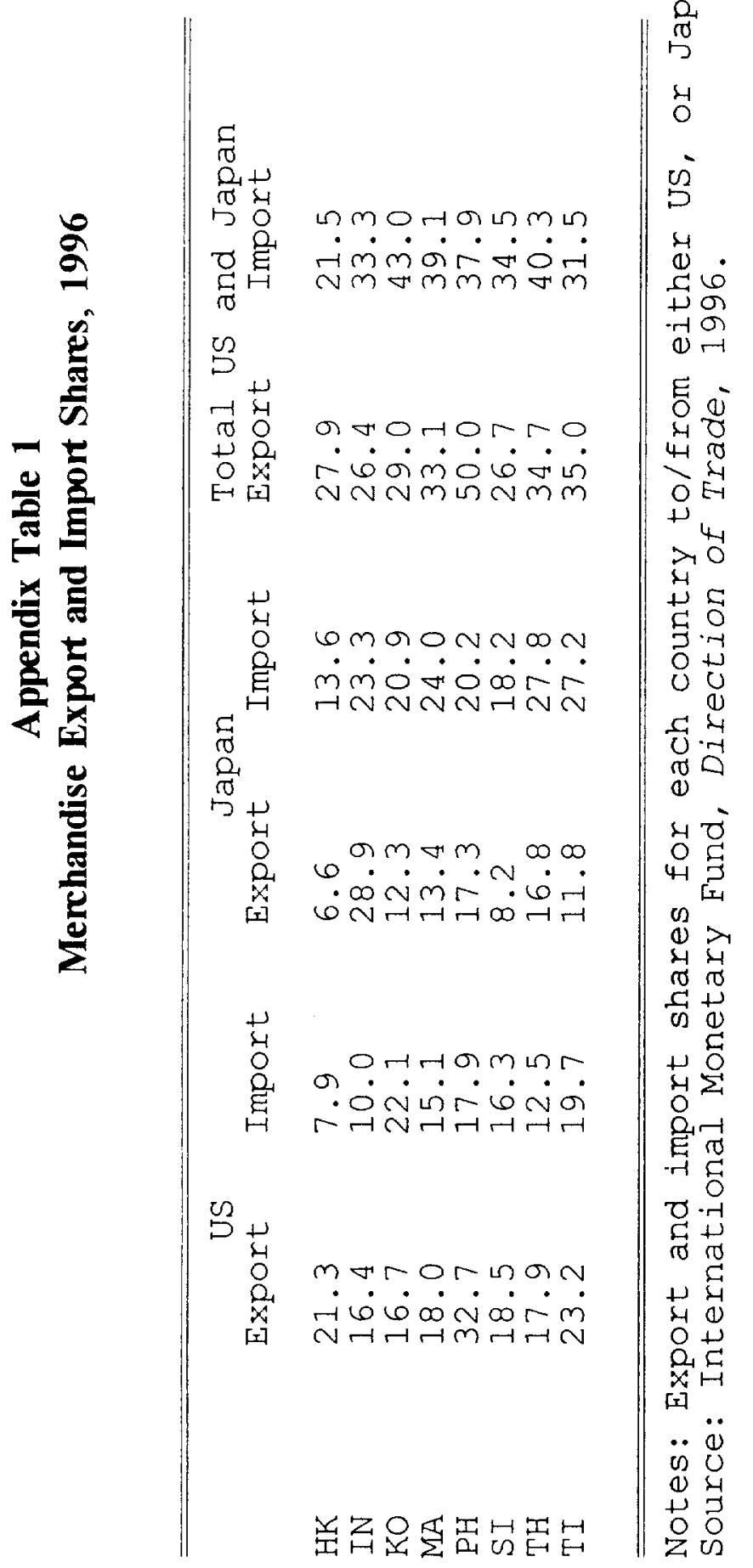




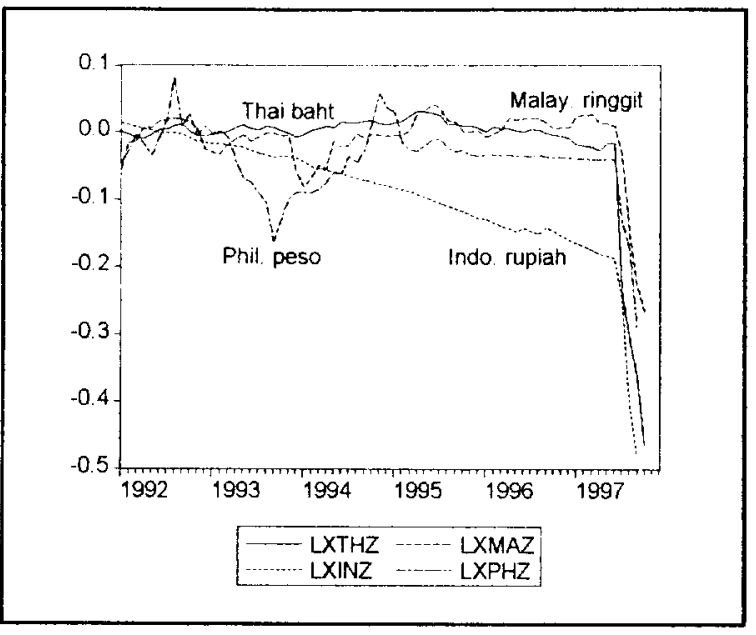

Figure 1: Thai, Indonesian, Malaysian and Philippine currencies, 1992-1997

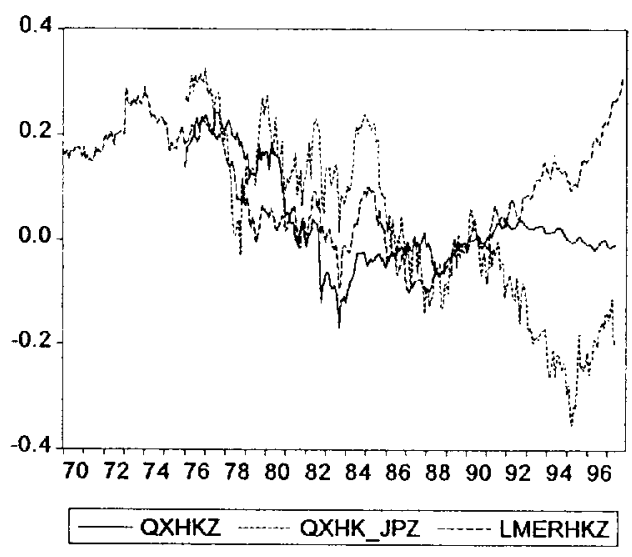

Figure 3: Hong Kong Export Price Deflated Exchange Rates against US\$ and Yen, and Trade-Weighted PPI Deflated Exchange Rate, 1990=0

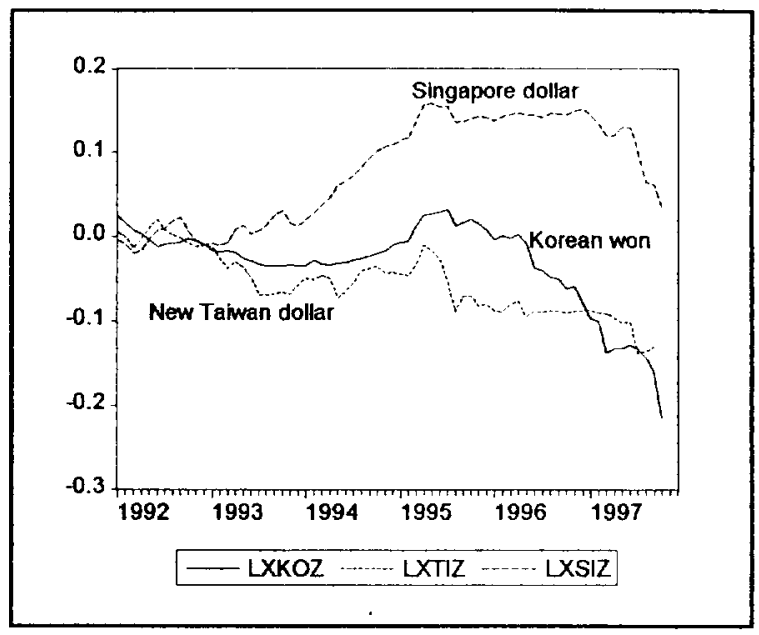

Figure 2: Korean, Taiwanese, and Singapore currencies, 1992-1997

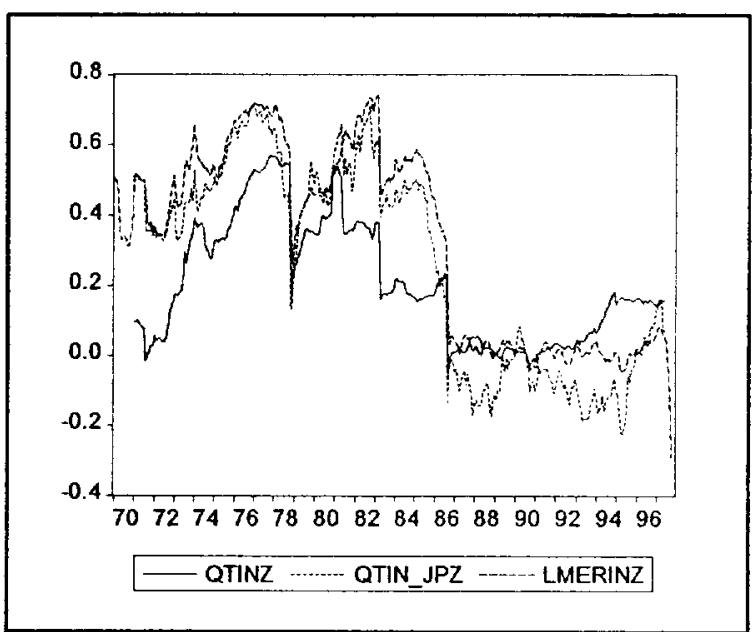

Figure 4: Indonesian PPI Deflated Exchange Rate against US\$, Yen, and Trade-Weighted, 1990 $=0$ 


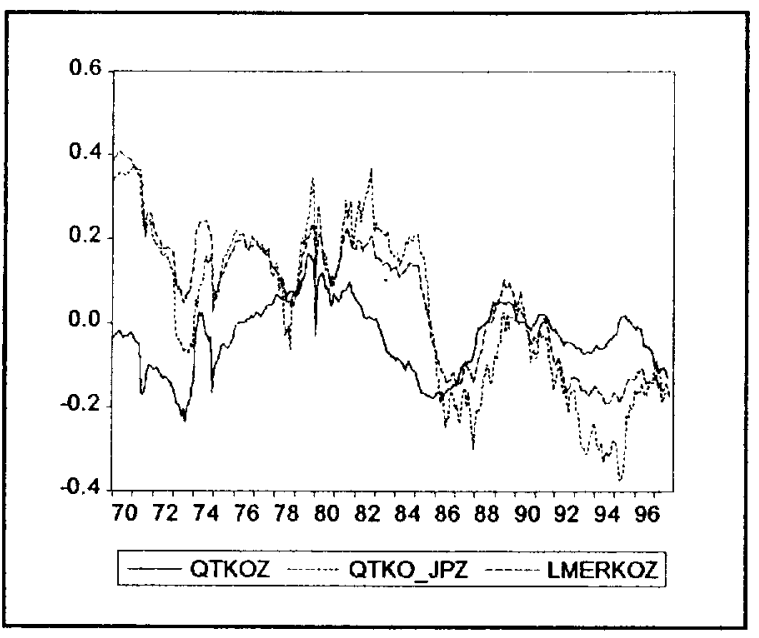

Figure 5: Korean PPI-Deflated Exchange Rate against US\$ and Yen, and TradeWeighted, $1990=0$

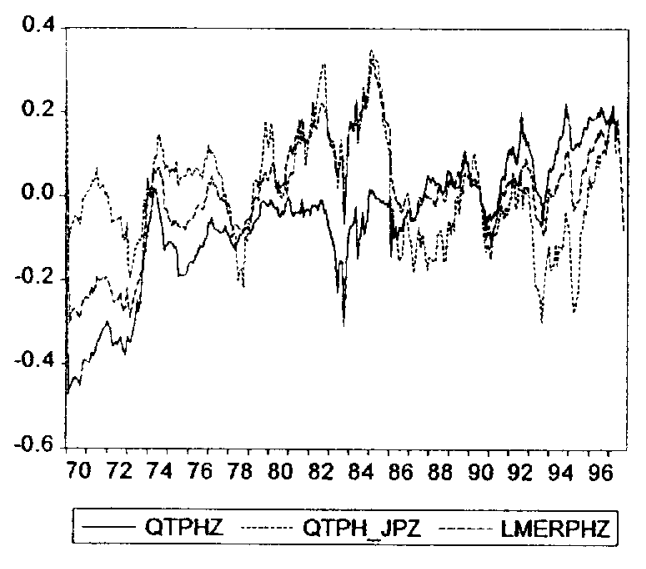

Figure 7: Philippine PPI-Deflated Exchange Rate against US\$ and Yen, and Trade-Weighted, $1990=0$

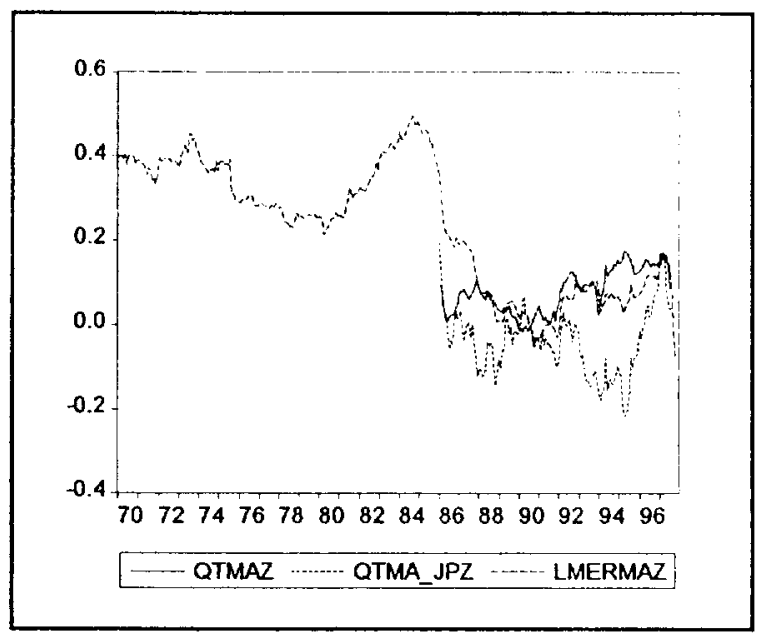

Figure 6: Malaysian PPI-Deflated Exchange Rate against US\$ and Yen, and Trade-Weighted, 1990=0

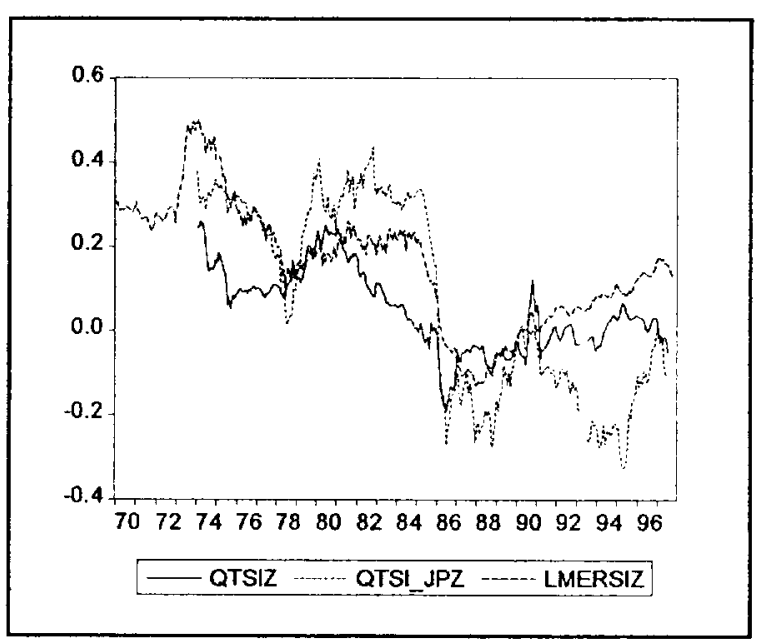

Figure 8: Singapore PPI-Deflated Exchange Rate against US\$ and Yen, and TradeWeighted, 1990=0 


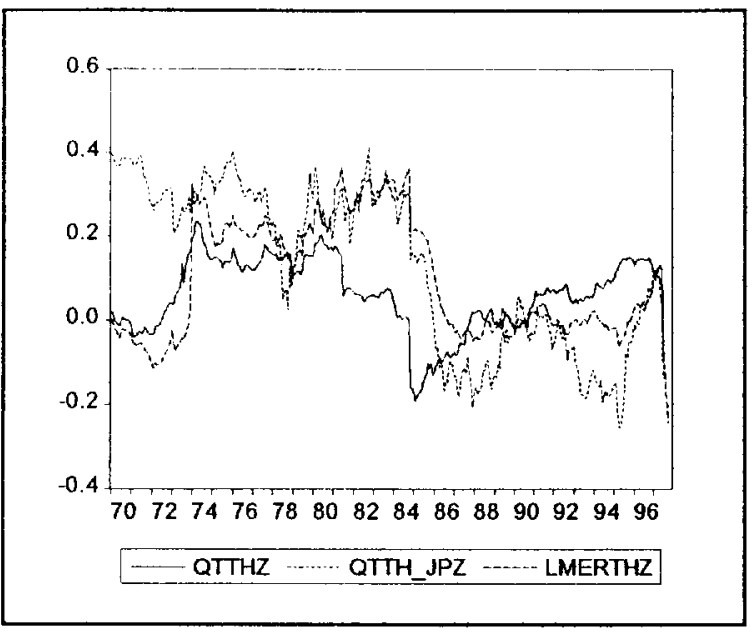

Figure 9: Thai PPI-Deflated Exchange Rate against US\$ and Yen, and Trade-Weighted, $1990=0$

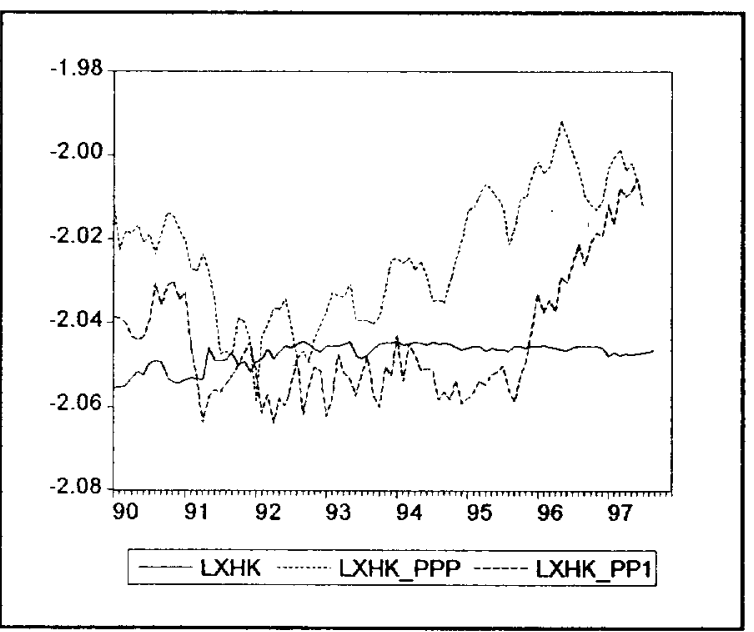

Figure 11: Hong Kong Dollar, Export Price Predicted and CPI w/trend-Predicted

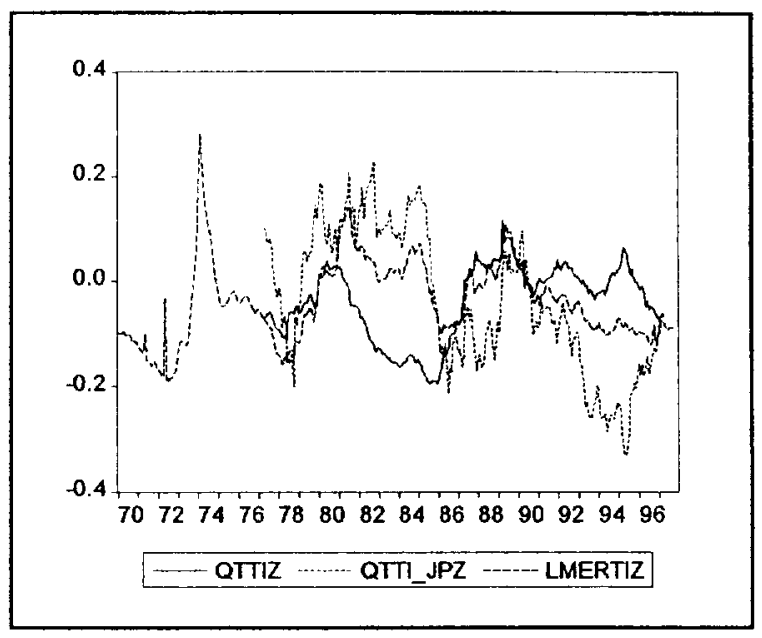

Figure 10: Taiwan PPI-Deflated Exchange Rate against US\$ and Yen, and TradeWeighted, $1990=0$

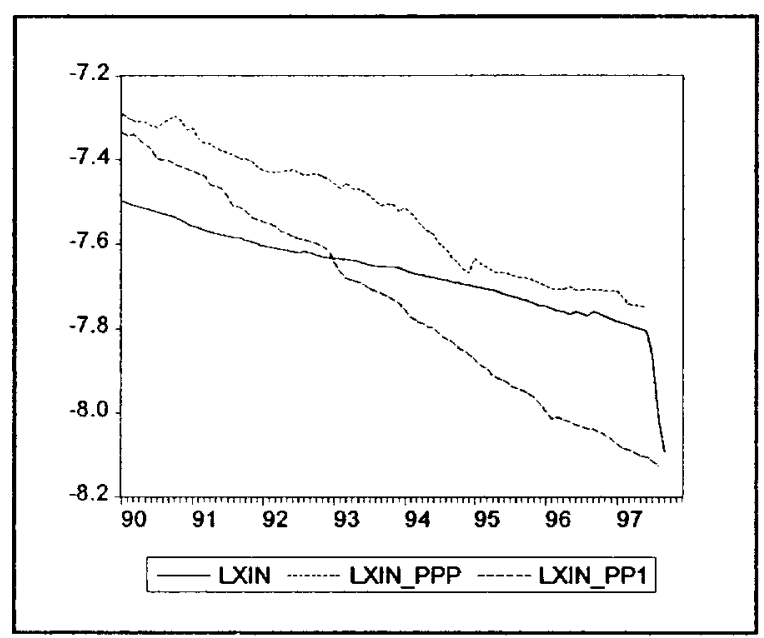

Figure 12: Indonesian Rupiah, PPIPredicted and CPI w/trend-Predicted 


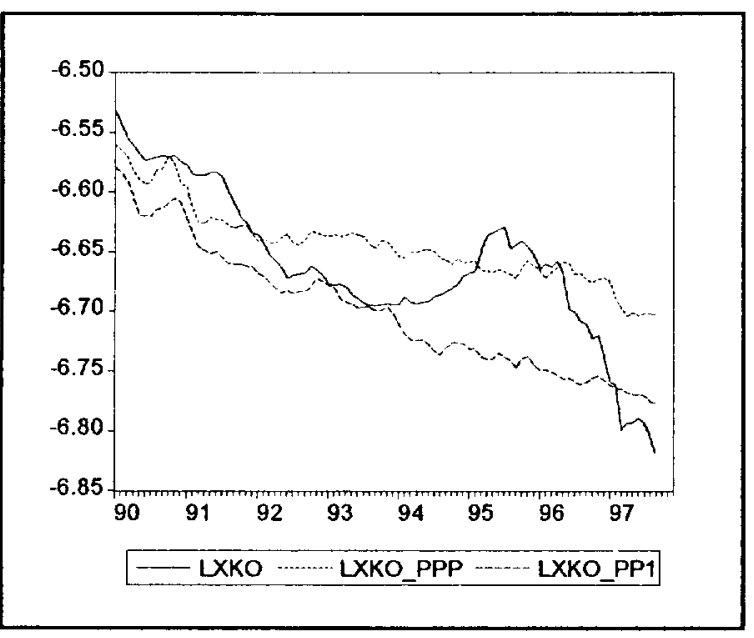

Figure 13: Korean won, PPI-Predicted and CPI w/trend-Predicted

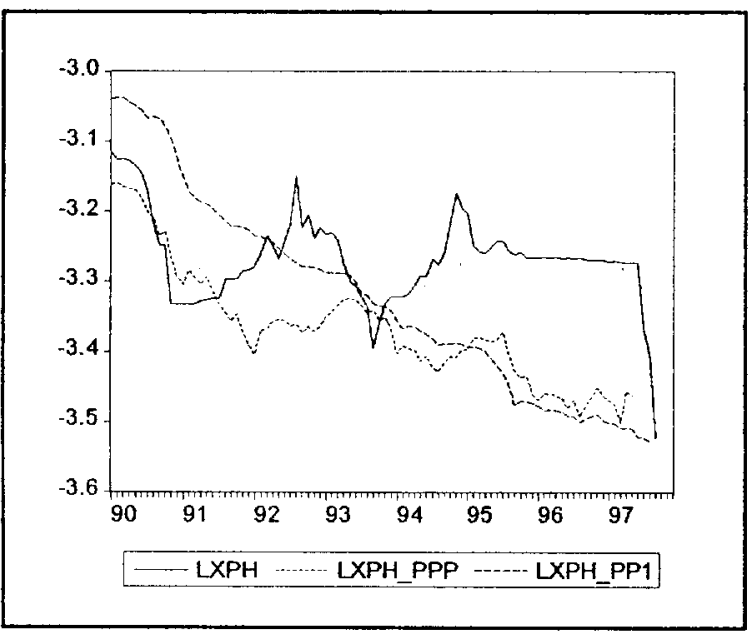

Figure 15: Philippine Peso, PPI-Predicted and CPI w/trend-Predicted

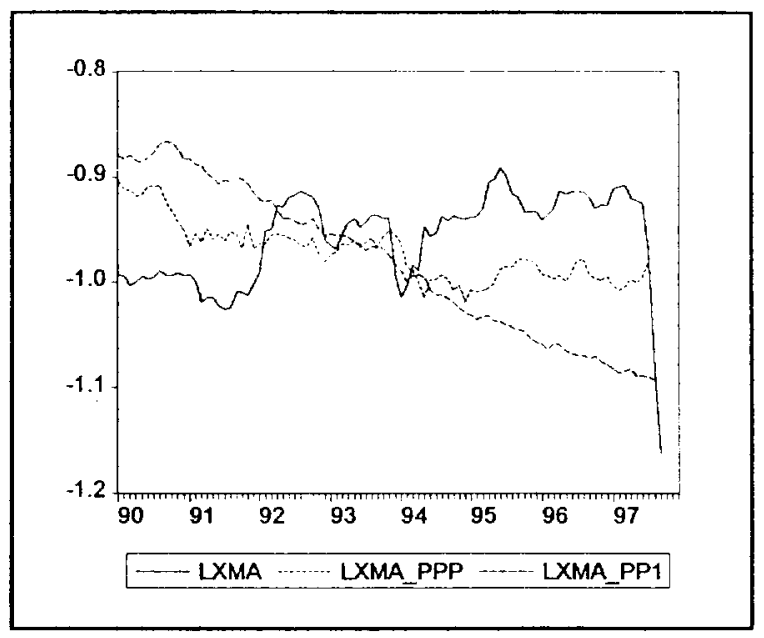

Figure 14: Malaysian Ringgit, PPI-

Predicted and CPI w/trend-Predicted

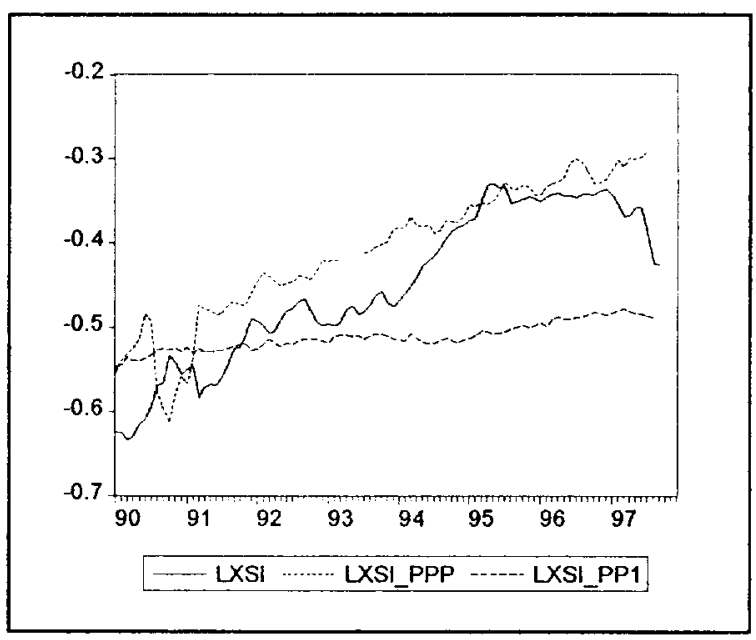

Figure 16: Singapore Dollar, PPI-Predicted and CPI w/trend-Predicted 


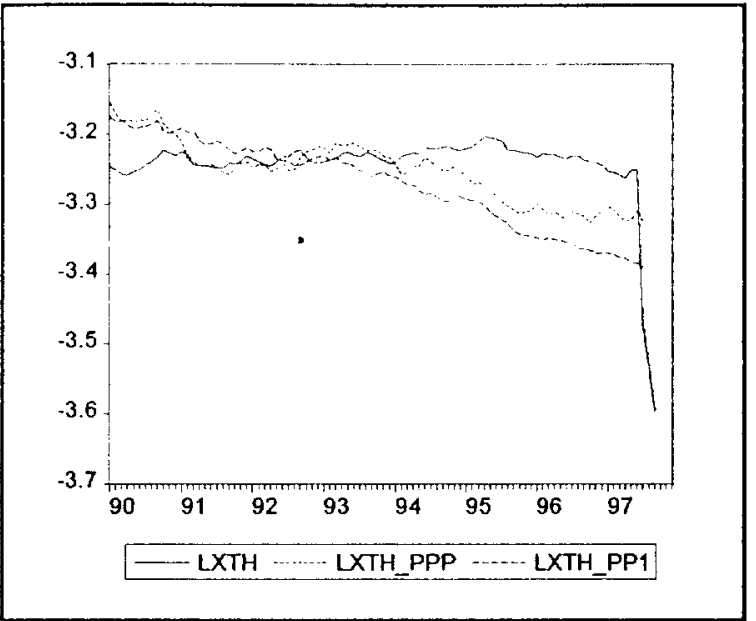

Figure 17: Thai Baht, PPI-Predicted and CPI w/trend-Predicted

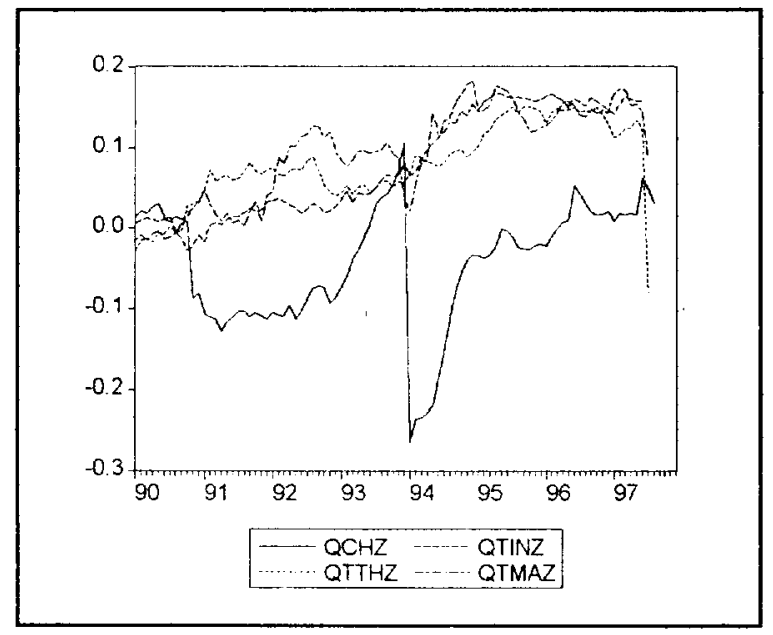

Figure 19: The CPI-deflated Chinese

Renminbi, and the baht, ringgit and rupiah, $1990=0$

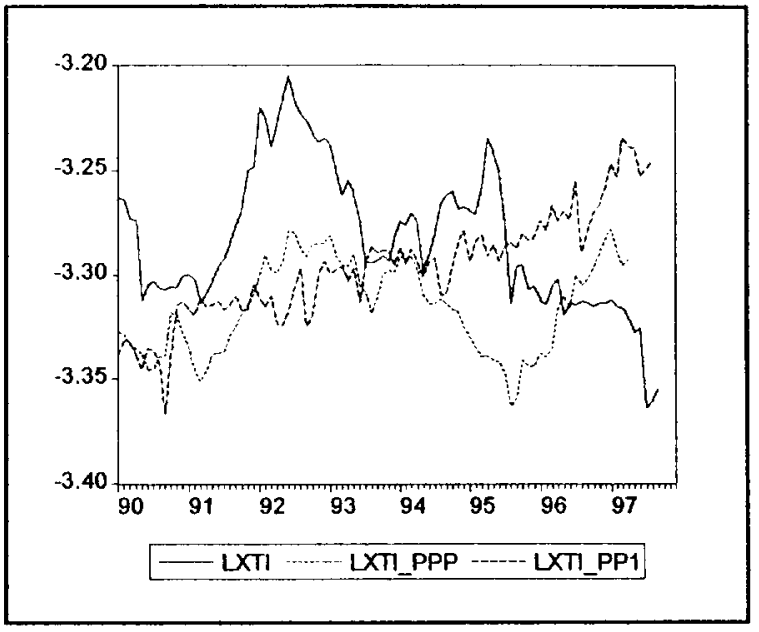

Figure 18: New Taiwan Dollar, PPIPredicted and CPI w/trend-Predicted 


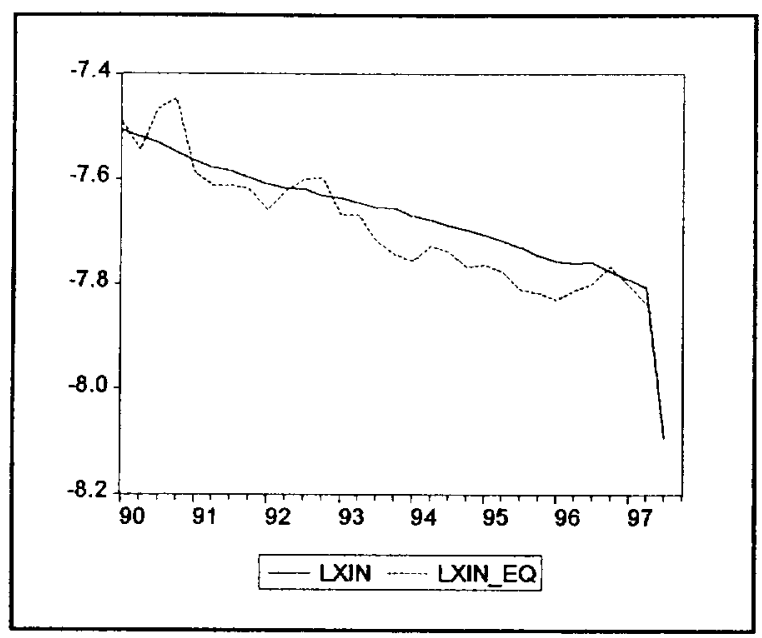

Figure 20: Indonesian Rupiah and Augmented Monetary Model-Predicted

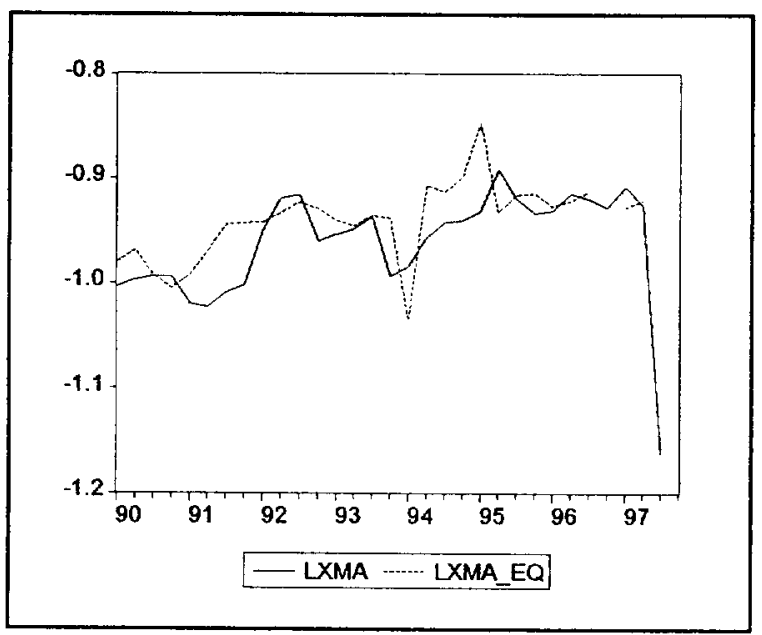

Figure 22: Malaysian Ringgit and Augmented Monetary Model-Predicted

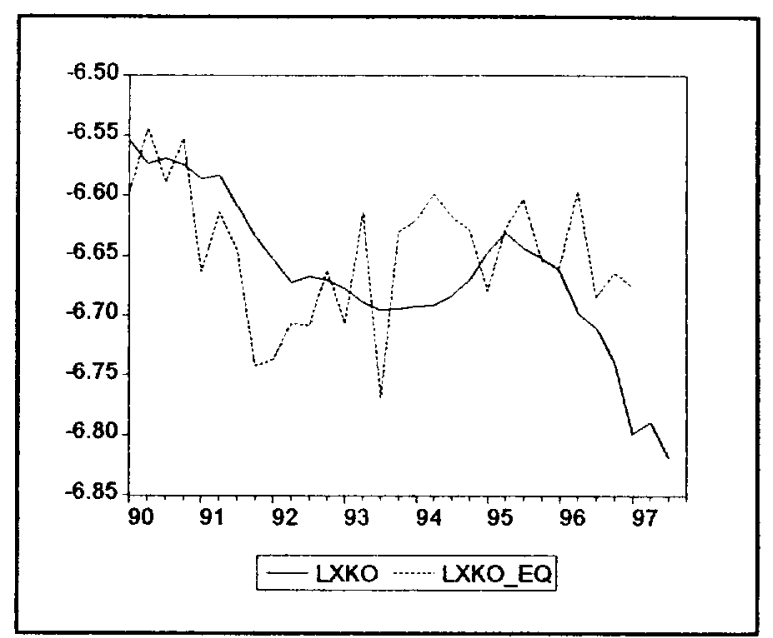

Figure 21: Korean Won and Augmented Monetary Model-Predicted

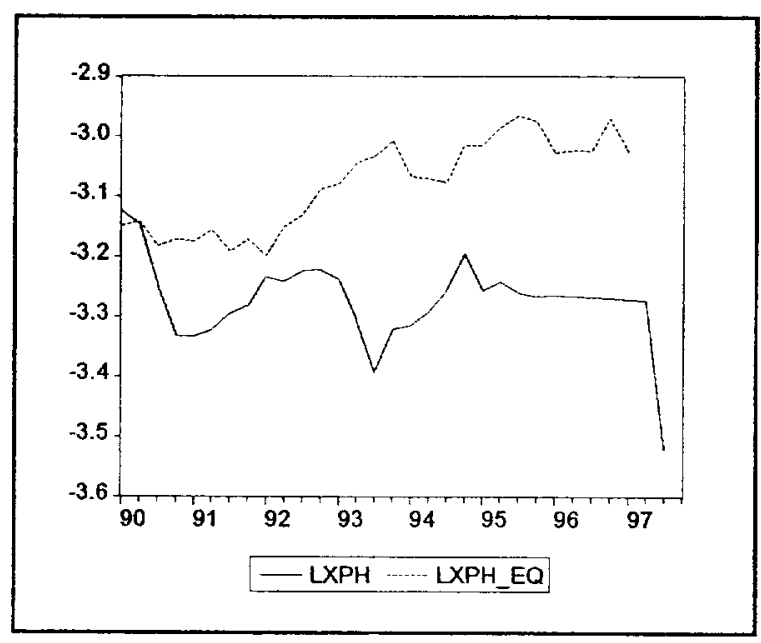

Figure 23: Philippine Peso and Augmented Monetary Model-Predicted 


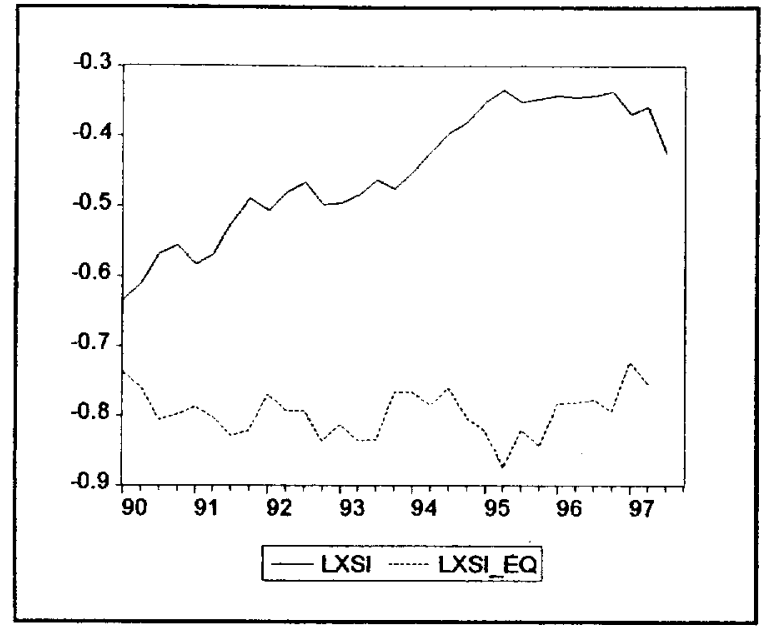

Figure 24: Singapore Dollar and Monetary Model-Predicted

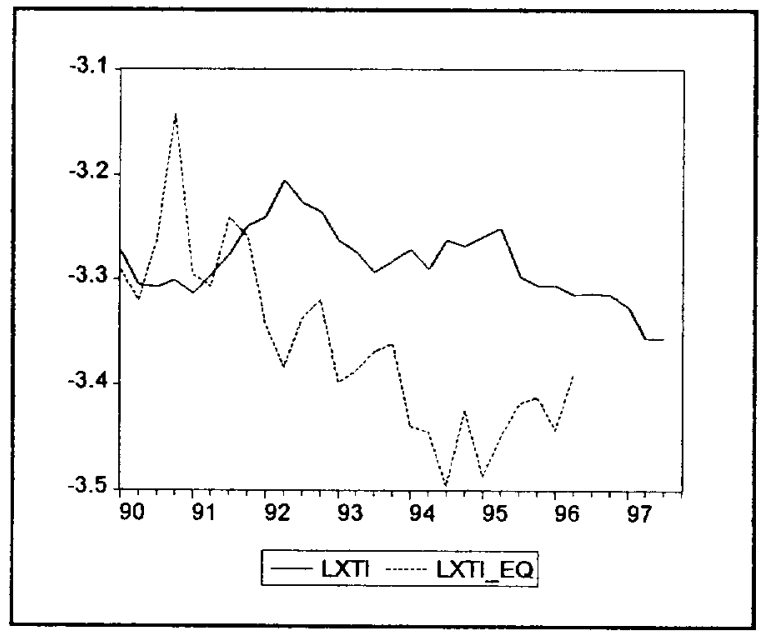

Figure 26: New Taiwan Dollar and Augmented Monetary Model Predicted

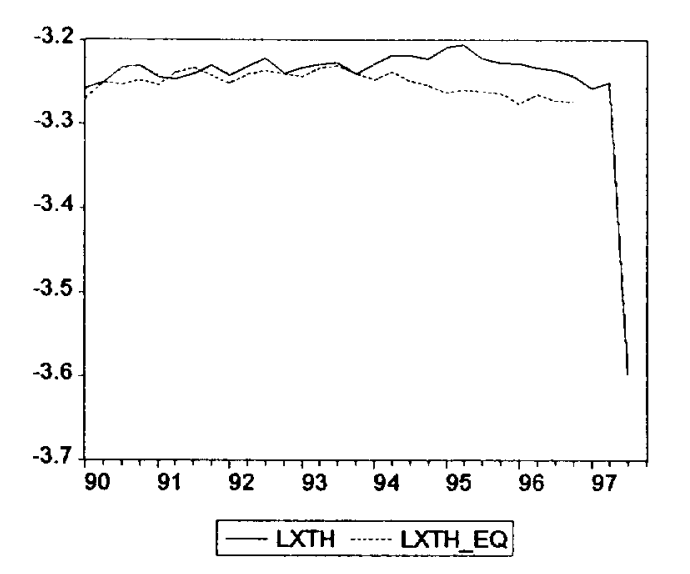

Figure 25: Thai Baht and Monetary ModelPredicted 